Adoption of improved grain legumes and dryland cereals crop varieties: A synthesis of evidence 


\section{Adoption of improved grain legumes and dryland cereals crop varieties: A synthesis of evidence}

Tesfaye Woldeyohanes, Karl Hughes, Kai Mausch, Judith Oduol 


\section{Correct citation:}

Woldeyohanes T, Hughes K, Mausch K, Oduol J. Adoption of improved grain legumes and dryland cereals crop varieties: A synthesis of evidence. Working paper No 316. World Agroforestry, Nairobi, Kenya. DOI https://dx.doi.org/10.5716/WP21022.PDF

Titles in the Working Paper Series aim to disseminate interim results on agroforestry research and practices and stimulate feedback from the scientific community. Other publication series from World Agroforestry include Technical Manuals, Occasional Papers and the Trees for Change Series.

Published by World Agroforestry

United Nations Avenue

PO Box 30677, GPO 00100

Nairobi, Kenya

Tel: +254(0)20 7224000, via USA +1650 8336645

Fax: +254(0)20 7224001, via USA +1 6508336646

Email: worldagroforestry@cgiar.org

Website: www.worldagroforestry.org

(C) World Agroforestry 2021

Working Paper no 316

\section{Photos:}

The views expressed in this publication are those of the author(s) and not necessarily those of World Agroforestry. Articles appearing in this publication may be quoted or reproduced without charge, provided the source is acknowledged.

All images remain the sole property of their source and may not be used for any purpose without written permission of the source. 


\section{About the authors}

Tesfaye Woldeyohanes is a postdoctoral fellow at CIFOR-ICRAF based in Nairobi, Kenya. His work involves quantitative impact assessment of agricultural policies, technology adoption, and economic modelling of ex- ante impact estimation of development projects and programs. Prior to joining ICRAF in 2020, Tesfaye worked for the Oromia Agricultural Research Institute in Ethiopia and as research assistant at the University of Bonn, Germany. He holds BSc in Agricultural Resource Economics and Management from Hawassa University in Ethiopia and a master's degrees in business and economics from the Swedish University of Agricultural Sciences (SLU) and food and resource economics from Bonn University. He expects to receive his doctorate degree in agricultural economics from Bonn University. Email: t.woldeyohanes@cgiar.org

Karl Hughes is an impact evaluation specialist with 22 years of experience in the international development sector, 18 of which have been based in Africa and Asia. He co-leads CIFORICRAF's Quality for Impact (Q4I) Group, overseeing its Impact Assessment and Acceleration function. He obtained his $\mathrm{PhD}$, which focuses on impact evaluation methodology, from the London School of Hygiene and Tropical Medicine, University of London (2012). He also holds a master's in environmental studies (1998) from York University, Canada, and a bachelor's degree in anthropology and philosophy (1994), from the University of British Columbia, Canada. Email: k.hughes@cgiar.org

Kai Mausch has worked on rural development for more than 10 years, exploring solutions to rural poverty from both agricultural and the non-agricultural perspectives. Before joining ICRAF, he worked for the International Crops and Research Institute for the Semi-Arid Tropics (ICRISAT) from 2010 to 2018 where he planned, coordinated, and implemented economic projects and program components at regional and global levels. Topics ranged from adoption, dissemination, and impact evaluation to value chain analysis and improved targeting of agricultural interventions in rural areas. Kai received his MSc while working with the International Centre of Insect Physiology and Ecology (ICIPE) in Nairobi and received his PhD in economics from the School of Economics and Management, Leibniz University of Hanover, Germany (2009). Email: k.mausch@cgiar.org

Judith Oduol is an agricultural economist based in Nairobi, Kenya. She holds a PhD from Kyushu University in Japan and a master's degree from the University of Antwerp in Belgium. Prior to joining ICRAF, Judith had worked for over 10 years with national research centres (Kenya Agricultural Research Institute, KARI) and regional research organizations (Forum for Agricultural Research in Africa, FARA). Judith's research interests span impact assessment, production economics, markets and value chain analysis, and policy and institutional analysis. Her current research focuses on identifying best bet methods for making markets work for marginalized groups, such as women and the poor. This includes designing monitoring, evaluation, and learning frameworks for projects at the Centre, as well as developing quantitative and qualitative methods for assessing the impact of value chain interventions on the livelihoods of marginalized households. Email: j.oduol@cgiar.org 


\title{
Abbreviations
}

$\begin{array}{ll}\text { CCC } & \text { country crop combinations } \\ \text { CIAT } & \text { International Center for Tropical Agriculture } \\ \text { CRP } & \text { CGIAR Research Program } \\ \text { DC } & \text { Dryland Cereal } \\ \text { DIIVA } & \text { Diffusion and Impact of Improved Varieties in Africa } \\ \text { DRC } & \text { Democratic Republic of Congo } \\ \text { FPVS } & \text { farmers participatory varietal selection } \\ \text { GLDC } & \text { grain legumes and dryland cereals } \\ \text { HOPE } & \text { Harnessing Opportunities for Productivity Enhancement } \\ \text { ICARDA } & \text { International Center for Agricultural Research in Dry Areas } \\ \text { ICRISAT } & \text { International Crops Research Institute for Semi-Arid Tropics } \\ \text { IITA } & \text { International Institute of Tropical Agriculture } \\ \text { IV } & \text { improved variety } \\ \text { SRF } & \text { strategy and result frameworks } \\ \text { SSA } & \text { sub-Saharan Africa } \\ \text { TL } & \text { tropical legume } \\ \text { TRIVSA } & \text { Tracking Improved Varieties in South Asia }\end{array}$

\begin{abstract}
Like other crop improvement programs, a key prerequisite for the CGIAR Research Program on Grain Legumes and Dryland Cereals (CRP GLDC) to generate large-scale impact is large-scale adoption. Hence, evidencing the breadth and depth of such adoption is both of intrinsic interest and important for estimating downstream impacts, such as improved food and nutritional security, income, resilience, and soil health. While various GLDC adoption studies have been undertaken, a recent effort to systematically review these studies and synthesize the results is lacking. We undertook such a review, identifying 69 studies and 35 independent country crop combinations (CCCs). To generate aggregated and updated estimates of GLDC improved varietal adoption, we devised and applied a procedure to estimate national cropping areas under such varieties and, in turn, the number of adopting households. Estimates derived from household surveys and expert opinion solicitation are treated with higher and lower levels of confidence, respectively. As of 2019, we estimate from higher confidence studies that improved GLDC crops were cultivated on 15.37 million hectares of land by 17.64 million households in CRP GLDC's 13 priority countries. With the inclusion of lower confidence studies, these numbers increase to 32 and 44.64 million, respectively. We are further confident that the program exceeded its adoption target of 8.9 million newly adopting households from 2011, particularly when likely spillovers vis-à-vis non-surveyed areas, non-priority countries, and non-priority crops in priority countries are considered.
\end{abstract}




\section{Contents}

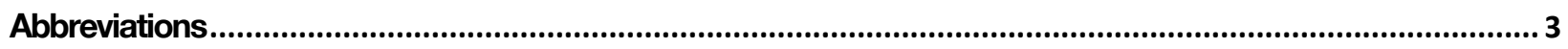

Abstract

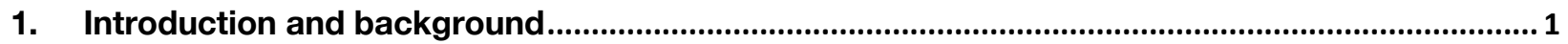

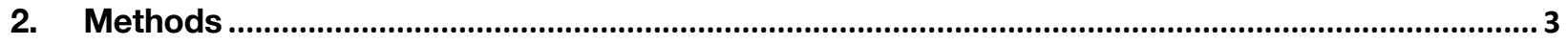

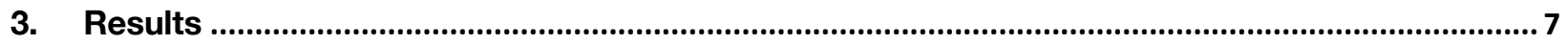

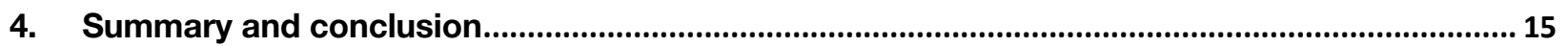

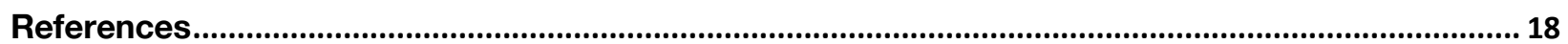




\section{Introduction and background}

The CGIAR ${ }^{1}$ Research Program for Grain Legumes and Dryland Cereals (CRP GLDC) undertakes crop improvement, complementary farm management, and policy research on grain legumes and dryland cereal crops in the semi-arid and sub-humid dryland agroecologies of sub-Saharan Africa (SSA) and South Asia. These agro-ecologies are characterized by high levels of poverty, malnutrition, soil degradation, and climate variability, which are key challenges specifically targeted in the CGIAR's Strategy and Result Framework (SRF). CRP GLDC aims to address these challenges by bolstering the productivity, profitability, resilience, and marketability of specific GLDC crops, on which farmers and others within these agro-ecologies significantly depend.

CRP GLDC has committed to achieving an ambitious set of impact targets. These contribute to those of the overall CGIAR system and include:

- 8.9 million farm households to have adopted improved GLDC varieties

- 4.4 million people assisted to exit poverty ( $50 \%$ women)

- $1.2 \%$ per year rate of yield increase for GLDC crops

- 12.7 million more people (50\% women) assisted to meet minimum dietary energy requirements

- 7.5 million women of reproductive age assisted to meet daily protein dietary requirements

- 4.9 million metric tons of cumulative carbon input to soils from increased GLDC productivity.

\subsection{CRP GLDC variety releases}

CGIAR has invested significantly in legume and cereal improvement research over the last four decades. This has been through CRP GLDC itself since 2018 and three preceding CGIAR Research Programs (CRPs): Grain Legumes, Dryland Cereals, and Dryland Systems. Direct funding for these CRPs has been augmented by bilaterally funded projects that constitute part of the CRPs, including those supported by the Bill \& Melinda Gates Foundation. Key CGIAR research centres involved in the larger research effort associated with GLDC crops include the International Crops Research Institute for the Semi-Arid Tropics (ICRISAT) (chickpea, groundnut, pigeon pea, millet, and sorghum), the International Institute of Tropical Agriculture (IITA) (cowpea and soybean), the International Center for Tropical Agriculture (CIAT) (common bean), and the International Center for Agricultural Research in Dry Areas (ICARDA) (lentils).

Recent reviews by Varshney et al. (2019) and Walker and Alwang (2015) show that CGIAR legume research has resulted in the release of 322 new varieties in 18 SSA countries alone between 2007 and 2017 (Table 1). Of these, 183 are new common bean varieties, with Ethiopia leading the release of such varieties, followed by Rwanda, the Democratic Republic of Congo (DRC), and Tanzania. New varieties of groundnut, cowpea, and

\footnotetext{
${ }^{1}$ CGIAR is a global research partnership for a food secure future dedicated to reducing poverty, enhancing food and nutrition security, and improving natural resources.
} 
chickpea have also been released in large number. Overall, the trend of varietal release for legume crops has increased more in recent years than in the early 2000 s.

Most of these varietal releases were facilitated by bilateral projects, including three Tropical Legume (TL) Projects (Monyo and Varshney, 2016). One report document that 304 improved varieties of legume crops have been developed in 15 countries in Africa, India, and Bangladesh (ICRISAT, 2020). Among South Asian countries, India has released the greatest number of new legume varieties. This includes 16 groundnut, 7 pigeon pea, and 3 chickpea varieties (Varshney et al. 2019).

Table 1: Grain legumes research output in SSA: Varietal releases (2007-2017)

\begin{tabular}{|c|c|c|c|c|c|c|c|c|}
\hline Country & $\begin{array}{c}\text { Chickpe } \\
a\end{array}$ & $\begin{array}{l}\text { Commo } \\
n \text { bean }\end{array}$ & Cowpea & $\begin{array}{c}\text { Ground- } \\
\text { nut }\end{array}$ & Lentil & $\begin{array}{c}\text { Pigeon } \\
\text { pea }\end{array}$ & Soybean & AlI \\
\hline Burundi & & 18 & & & & & & 18 \\
\hline Burkina Faso & & & 6 & & & & & 6 \\
\hline DRC & & 22 & & & & & & 22 \\
\hline Ethiopia & 11 & 28 & & & 1 & & & 40 \\
\hline Ghana & & & 4 & & & & & 4 \\
\hline Kenya & 9 & 17 & & & & 3 & 7 & 36 \\
\hline Malawi & & 13 & & 7 & & 3 & & 23 \\
\hline Mali & & & 7 & 9 & & & & 16 \\
\hline Mozambique & & 8 & & 6 & & 4 & & 18 \\
\hline Niger & & & 5 & 5 & & & & 10 \\
\hline Nigeria & & & 7 & 3 & & & 1 & 11 \\
\hline Senegal & & & & 6 & & & & 6 \\
\hline Sudan & 1 & & & & & & & 1 \\
\hline Rwanda & & 25 & & & & & & 25 \\
\hline Uganda & & 18 & & 12 & & & & 30 \\
\hline Tanzania & 4 & 21 & & 12 & & 2 & 2 & 41 \\
\hline Zambia & & 6 & & & & 2 & & 8 \\
\hline Zimbabwe & & 7 & & & & & & 7 \\
\hline All SSA & 25 & 183 & 29 & 60 & 1 & 14 & 10 & 322 \\
\hline
\end{tabular}

Source: Varshney et al.(2019) and Walker and Alwang (2015)

Unlike legumes, no comparable review of recent varietal releases for dryland cereals has yet been undertaken. However, an ICRISAT-led project, Harnessing Opportunities for Productivity Enhancement (HOPE), documented that 49 cultivars of dryland cereals (25 sorghum, 13 pearl millet, and 11 finger millet) were released between 2009 and 2016 (ICRISAT, n.d.). ${ }^{2}$

\subsection{Previous work documenting GLDC adoption}

Releasing new crop varieties does not automatically lead to their adoption, particularly among key target groups. Consequently, farming household surveys have been conducted by CGIAR centres and others to ascertain levels of adoption and factors that

\footnotetext{
${ }^{2}$ http://exploreit.icrisat.org/profile/Sorghum/193
} 
facilitate and constrain it (Tripp 2011; Pacheco 2014; Walker and Alwang 2015). There have also been several noteworthy attempts to synthesize the results of these studies. One study, for example, by Pachico (2014) reviewed and synthesized the work carried out by over 30 impact assessment and adoption studies conducted in more than 20 countries in Africa.

The Diffusion and Impact of Improved Varieties in Africa (DIIVA) and Tracking Improved Varieties in South Asia (TRIVSA) projects have also documented varietal adoption and diffusion for various crops (including those related to GLDC's mandate) in SSA and South Asia from the period between 1998 and 2010 (Walker and Alwang 2015). This was a large body of work that involved comparing household survey, local informant, and expert opinion approaches to estimating national-level adoption of improved crop varieties.

\subsection{Our contribution and approach}

Our paper builds on and updates these efforts by reviewing and synthesizing more recent adoption studies and data, while also identifying gaps. We treat the Walker and Alwang (2015) adoption estimates from 2010 to 2014 survey data as our benchmark, and we examine what has changed since and where. However, we treat estimates derived through survey data and expert opinion with higher and lower levels of confidence, respectively, and, consequently, provide two sets of estimates. Noting that adoption is a dynamic process, we estimate current levels based on the latest available data combined with conservative projections, as needed.

\subsection{Structure}

In the next section, Methods, we describe our hybrid approach of identifying and synthesizing evidence from recent adoption studies, coupled with the use of trends in adoption, to estimate current levels. In Section 3, Results, we review the nature of the adoption studies emanating from our systematic literature search and what they reveal. We then present our estimates of current levels of improved GLDC adoption by crop type and by country following the application of our 'updating' procedure, both in absolute levels and from 2011 onwards (i.e., since beginning of CRP Phase 1). In Section 4 , we summarize key findings and present recommendations.

\section{Methods}

To obtain recent estimates of GLDC varietal adoption, we carried out a systematic review of adoption-related studies conducted between 2007 and 2020, focusing on countries and crops targeted by CRP GLDC. We chose to include studies published after 2006 to capture research carried out under the first phase of the three abovementioned CRPs, as well as the two major bilateral projects, TL and HOPE. In this section, we describe the process followed, as well as our national-level adoption estimation approach.

\subsection{Search methods and selection criteria}

We relied on three methods to compile post-2006 GLDC adoption evidence: (a) an online search targeting scientific publications and grey literature available online; (b) a search 
of relevant organizational archives; and (c) direct communication with CRP GLDC scientists for relevant data and reports not yet published online.

For the online search, we used Google Scholar and a string that combined 'adoption' with each of CRP GLDC's target countries and crops as keywords. We retrieved additional grey literature not published online from organizational archives, which included those of ICRISAT, IITA, and CGIAR's Monitoring Evaluation and Learning database. During our validation process and corresponding communications with eight CRP GLDC scientists, we obtained five additional studies unavailable from any of the above.

\subsection{Inclusion and exclusion criteria}

From our search, we retained papers and other relevant documents that met the following eligibility criteria:

- Focus on one or more of CRP GLDC's target crops. These include seven grain legumes (chickpea, common bean, cowpea, groundnut, lentil, pigeon pea, and soybean) and two dryland cereals (pearl millet and sorghum).

- Focus on one or more of CRP GLDC's 13 target countries: 11 in SSA (Burkina Faso, Ethiopia, Malawi, Mali, Mozambique, Niger, Nigeria, Sudan, Tanzania, Uganda, and Zambia) and 2 in South Asia (India and Myanmar).

- Focus on adoption of one or more of the GLDC improved crop varieties by farmers in the priority countries.

- Timeframe: 2007-2020 to cover the first two phases of the CGIAR's CRPs, as well as research carried out under major bilateral projects.

- Type of publication: adoption and impact studies, including peer-reviewed journal articles, conference papers, working papers, book chapters, and discussion papers that use primary data; and project annual reports and baseline and endline evaluation reports.

- Only one version of the same study (e.g., only the published paper and not its associated working paper).

- Published in English.

Documents excluded from our review include:

- Studies based on unrepresentative samples, which would, thereby, prevent extrapolation.

- Studies based on experimental or farmer participatory varietal selection (FPVS) trials, as such would be similarly problematic for drawing population-wide inferences.

\subsection{Validation}

We coded relevant studies and documents meeting the above criteria and tabulated their associated metadata in a spreadsheet. This spreadsheet was shared with key CGIAR scientists involved in GLDC research for validation. They also provided other relevant documents and data not captured in our search process. Through this process, several 
errors in our captured adoption estimates were identified and corrected (i.e., for cowpea in Nigeria and common bean in Ethiopia).

\subsection{Adoption estimation and updating method}

Our objective was to use the screened studies and documents as a means of estimating the number of households that have adopted improved GLDC varieties both overall and from 2011 onwards.

However, we encountered four main issues:

- Varying units. Many studies do not use 'household' as the main unit for measuring adoption. For example, the area of land under improved varieties measured as a percentage of total area grown vis-à-vis the crop is commonly used. Several other studies also use the percentage of plots under improved varieties or share of improved varieties of seeds used by farmers.

- Temporal extrapolation challenges. The estimates associated with the 35 shortlisted studies range from as early as 2010 to as late as 2020. Thus, many estimates do not necessarily reflect current levels of GLDC crop varietal adoption.

- Geographic extrapolation challenges. The adoption estimates ascertained from household survey data correspond to the main crop-growing areas or project intervention areas in the target countries. Hence, we could not use these estimates to directly infer adoption at the national level. The DIIVA and TRISVA studies provide national-level estimates, but many of these were derived through a Delphi-informed expert estimation method, rather than survey data (Walker and Alwang, 2015), leading to our fourth issue.

- Survey data versus expert opinion. Of our 35 shortlisted studies, 19 are informed by survey data, while the remaining 16 are based on the expert opinion solicitation method used in the DIIVA/TRISVA studies. There is significant variation in the extent to which the resulting expert opinion estimates are consistent with those derived from adoption surveys (Walker and Alwang, 2015). For some crop types, there is reasonable consistency, but this is not the case for others.

Our adoption estimation and updating method addresses these four issues (Figure 1). We began by estimating the national adoption rate (Step 1), particularly for those studies only providing region (or sample area) adoption estimates. Specifically, we multiplied the region-specific estimates by the share of cropping area that this rate applies to (i.e., the cropping area targeted by the study) vis-à-vis the national cropping area. For example, if the share of the study's sampling area represents $75 \%$ of the national cropping area, a sample adoption rate of $40 \%$ would convert to a national adoption rate of $30 \%(75 \%$ $\times 40 \%=30 \%$ ). CGIAR centres tend to administer adoption surveys in growing regions where the improved variety was promoted. Consequently, we do not expect adoption rates to be similar in other regions. Indeed, our approach is conservative, as the resulting national estimates assume that no spillovers of the improved varieties to non-surveyed regions has taken place. Consequently, our adoption estimates for the national level 
likely systematically underestimate actual adoption levels and can, therefore, be treated as 'lower bound' estimates.

Second, we updated our national adoption estimates up to 2019 (the latest available year of FAOSTAT data $(\mathrm{FAO}, 2020)^{3}$ using the average annual adoption growth rate for each crop (Step 2). For example, for a national adoption rate of 38\% in 2016 with an average annual adoption growth rate of $2 \%$, the corresponding 2019 estimate would be $44 \%$. However, adoption growth rates are only reported in some of our shortlisted studies. Out of the 19 higher confidence studies, 12 involved at least two survey rounds. For these, we were able to compute the adoption growth rate, which we used to update our estimates to 2019. For the other studies, we computed the adoption growth rate using changes in yield derived from FAOSTAT data as a proxy. We assume that the adoption growth rate per year is proportional to the long-term average yield growth rate for that crop. We acknowledge the inherent limitations, given that yield is affected by factors other than varietal adoption (e.g., weather and management practices).

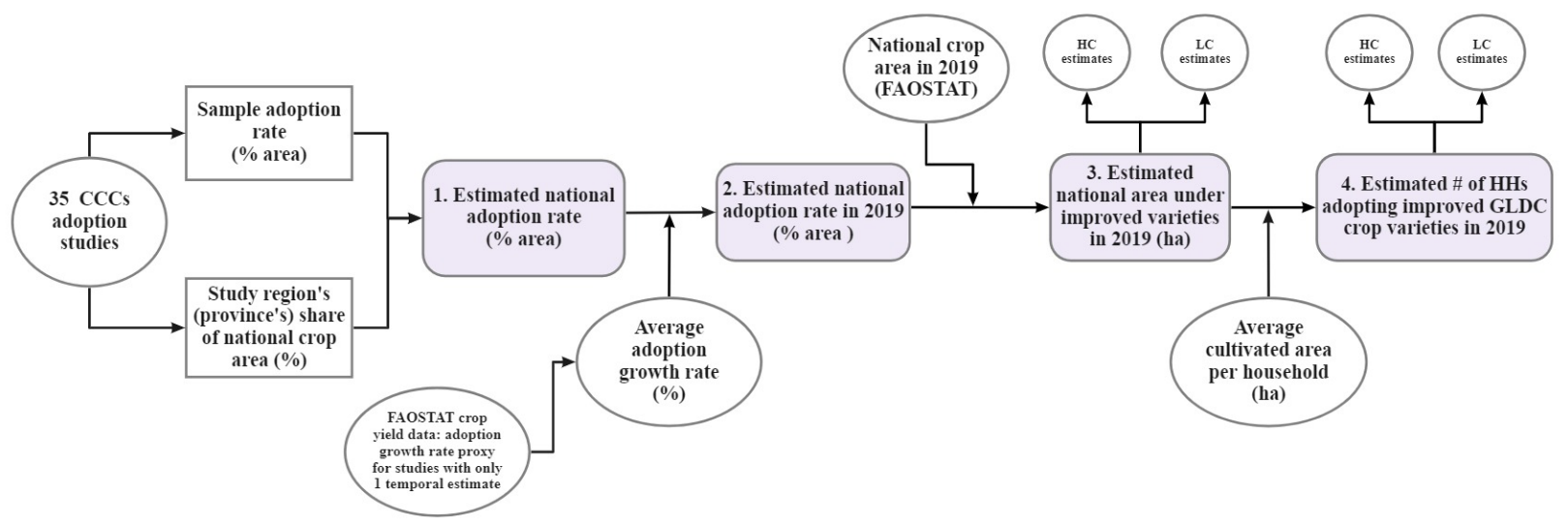

Figure 1. Estimation approach of adoption level at the national level

Notes: $\mathrm{CCC}=$ country by crop combination; $\mathrm{HC}=$ higher confidence; $\mathrm{LC}=$ lower confidence; $\mathrm{HH}$ = household

Next, we multiplied our estimated updated national adoption rate by the national area under the crop during the survey period and in 2019 (obtained from FAOSTAT), thereby deriving the estimated number of hectares under the improved variety in question (Step 3). We then we divided these results by data on the average area cultivated per household to derive an estimated number of adopting households (Step 4). ${ }^{4}$ Finally, we adjusted for potential double counting by only taking the highest number of households associated with a specific crop in areas where there is geographic overlap in the cropgrowing area. This approach is, again, conservative because it assumes that all households in these areas of overlap that adopt the most popular improved GLDC variety also adopt the other improved varieties. This is unlikely to always be the case, thereby resulting in a likely underestimation of total number of households adopting one or more GLDC improved variety.

\footnotetext{
${ }^{3} \mathrm{FAO}$ national crop area data for each crop in the target countries is provided in Appendix A.

${ }^{4}$ The data is obtained from the selected studies and other sources when this not available from the selected studies (see Appendix C)
} 
For Steps 4 and 5, we generated higher and lower confidence estimates. Complementing the findings of Walker (2015), we find that that expert opinion derived adoption estimates are consistently higher than those associated with will follow-up household surveys (cf. Manda et al., 2019; Mwakimata, 2018; Tufa et al., 2019). Therefore, we treated such adoption estimates as less reliable and used them to estimate current levels of varietal adoption only when household survey data were unavailable, thereby leading us to generate two sets of estimates. (See Appendix B for how the shortlisted studies are grouped by level of confidence.)

\section{Results}

In this section, we first present the results of our search, including a brief description of 69 filtered adoption studies. We then provide a detailed synthesis of the results by target country and crop combination (CCC).

\subsection{Description of the selected adoption studies}

Our online search returned 203 studies and 17 additional studies were identified through other sources, bringing the total to 220 (Figure 2). Of these, 67 were removed as duplicates and the remaining 153 studies were screened based on their titles and abstracts, which led to 63 studies being dropped. Of the 90 remaining studies, 63 met our inclusion criteria. Our validation process retrieved 6 additional adoption studies from Center scientists, bringing the total to 69 . From these, we relied on only $35 \mathrm{CCCs}$ with the latest adoption data to generate our adoption estimates. However, we used the 34 older studies to inform our adoption growth rate computations, as per our modelling approach presented in Section 2. 


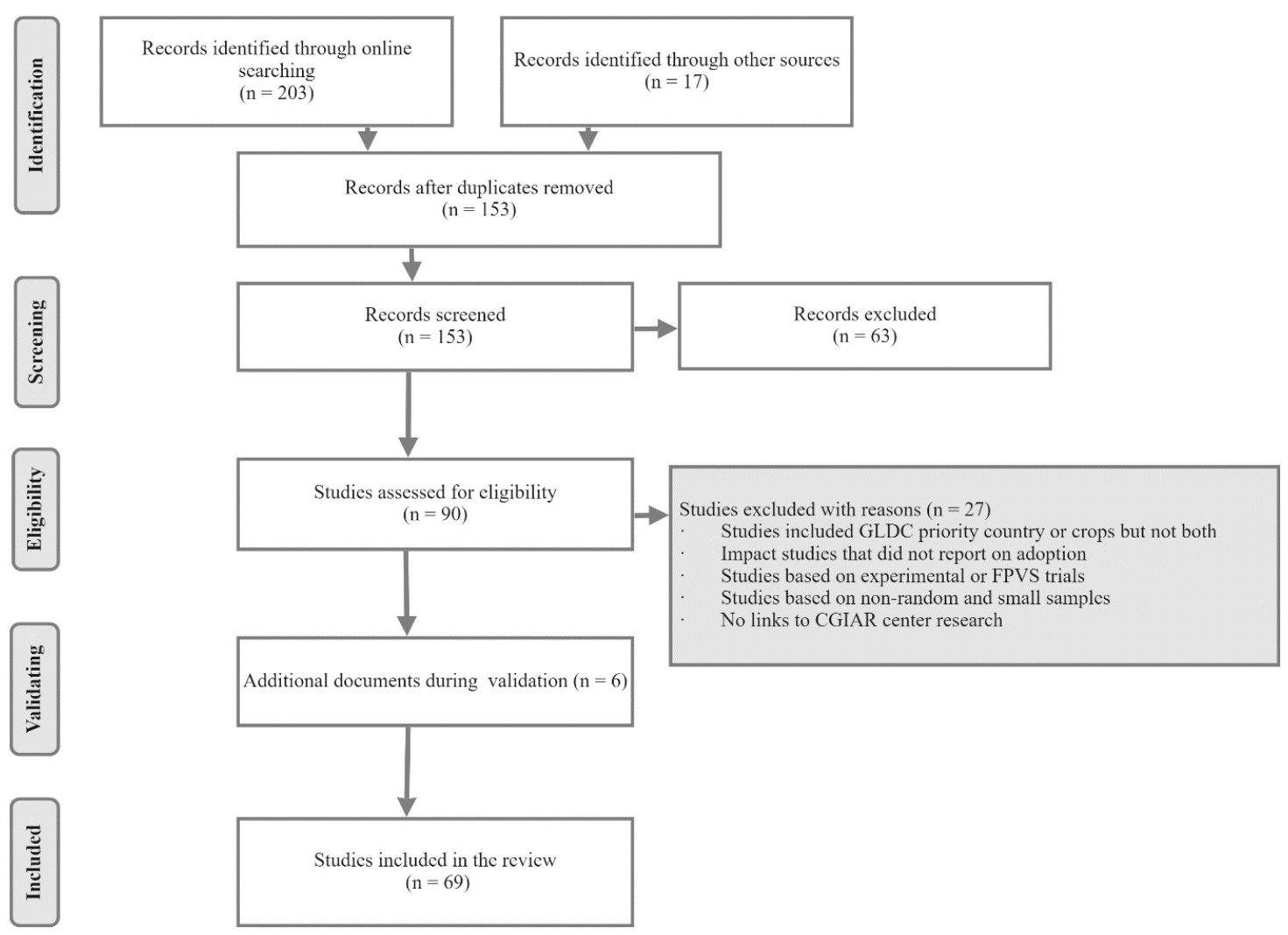

Figure 2. Search and screening process for adoption studies of improved varieties of crops targeted in GLDC

Notes: FPVS = farmers' participatory varietal selection,

Most of the retrieved studies are articles published in peer-reviewed journals and book chapters, followed by research reports of different types (

Figure 3).

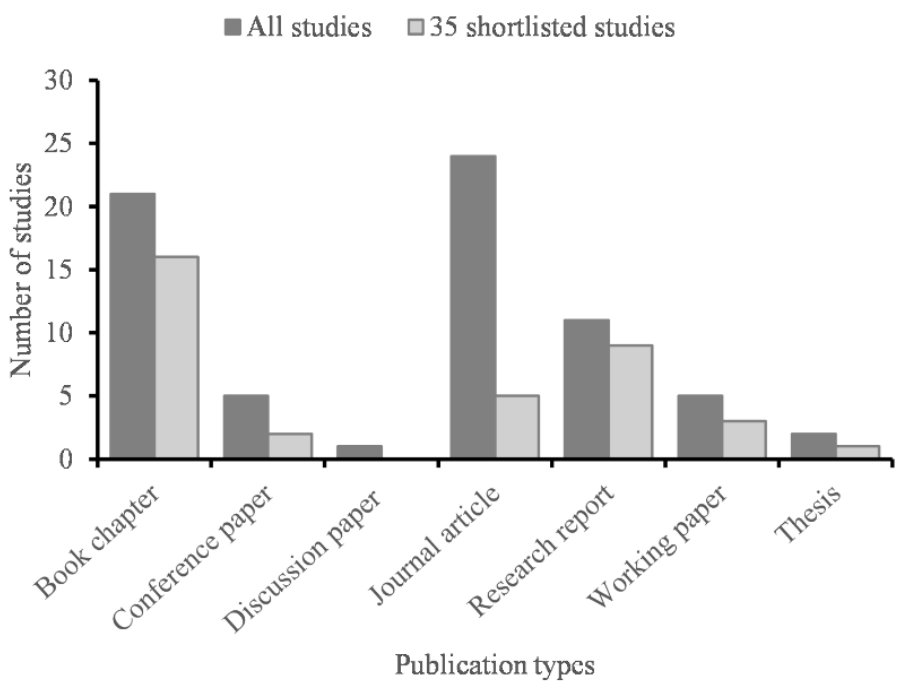

Figure 3. Type of scientific publications reviewed 
Figure 4 shows the number of studies across survey years. ${ }^{5}$ The year 2010 stands out as it includes projects summarized in Walker and Alwang (2015). Of the 35 studies that form the core basis of our estimates, only 18 are based on household data collected after 2010, revealing a lack of up-to-date information on the level of GLDC crop adoption. This is the rationale for implementing our adoption rate temporal extrapolation approach described in Section 2.

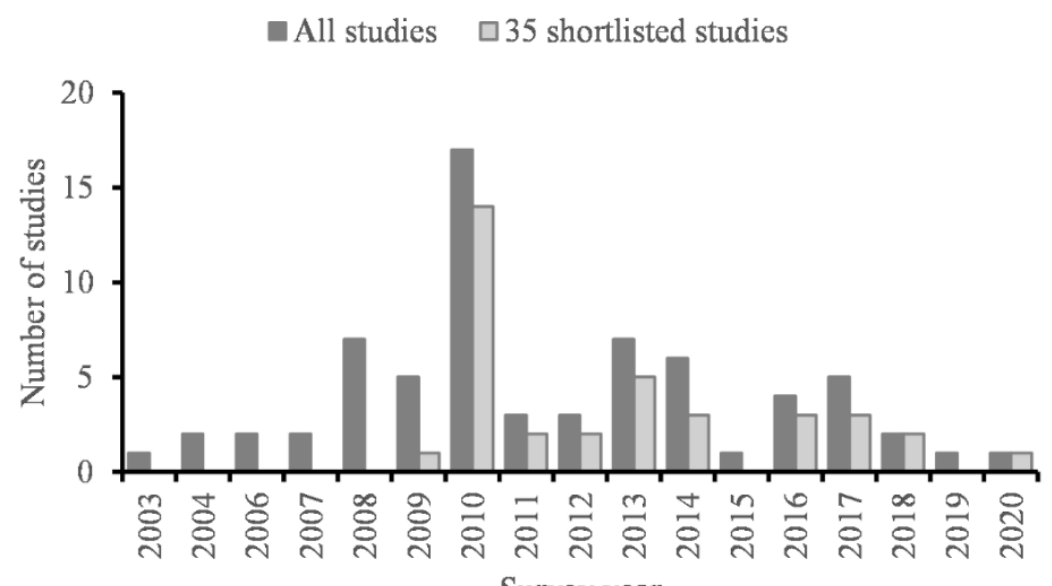

Survey year

Figure 4. Number of studies per survey year

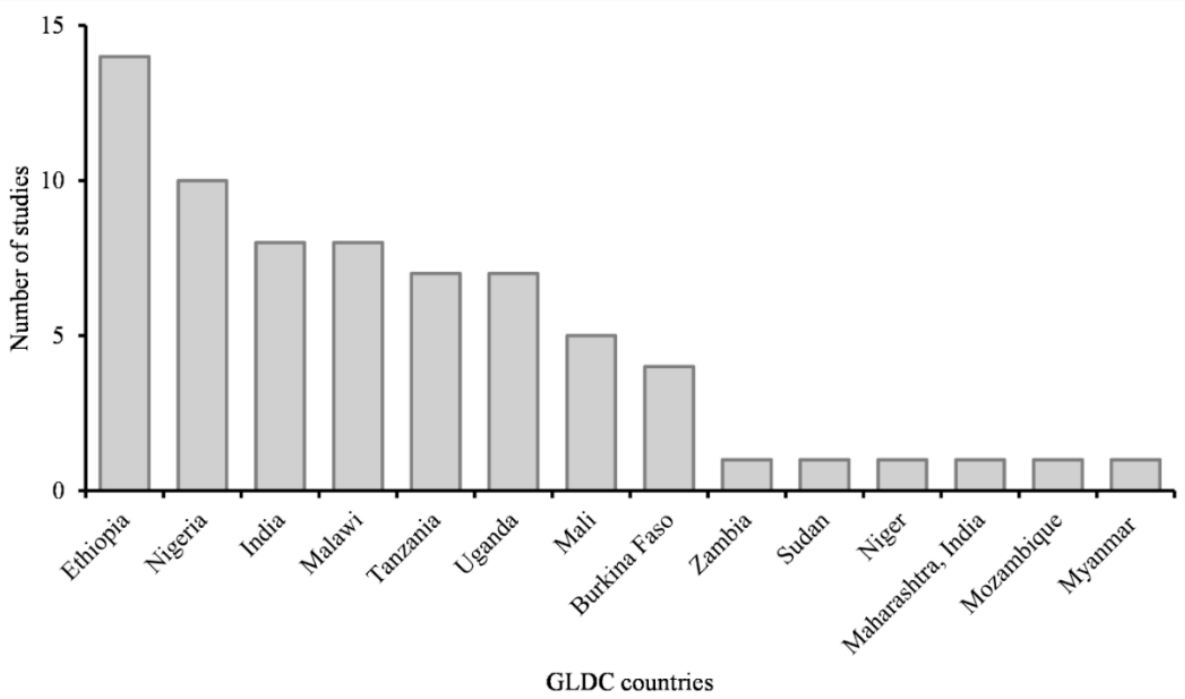

Figure 5 and Figure 6 present the number of adoption studies by CCC. Ethiopia, Nigeria, and Malawi account for the most SSA studies, whereas India dominates the South Asia region. This is partly a reflection of the relatively high number of GLDC crops released in these countries. The highest number of adoption studies pertain to groundnuts (13 studies), while more than five studies were completed for most of the other crops.

\footnotetext{
${ }^{5}$ Survey year refers to the year data were collected through household surveys and ascertained via expert opinion.
} 


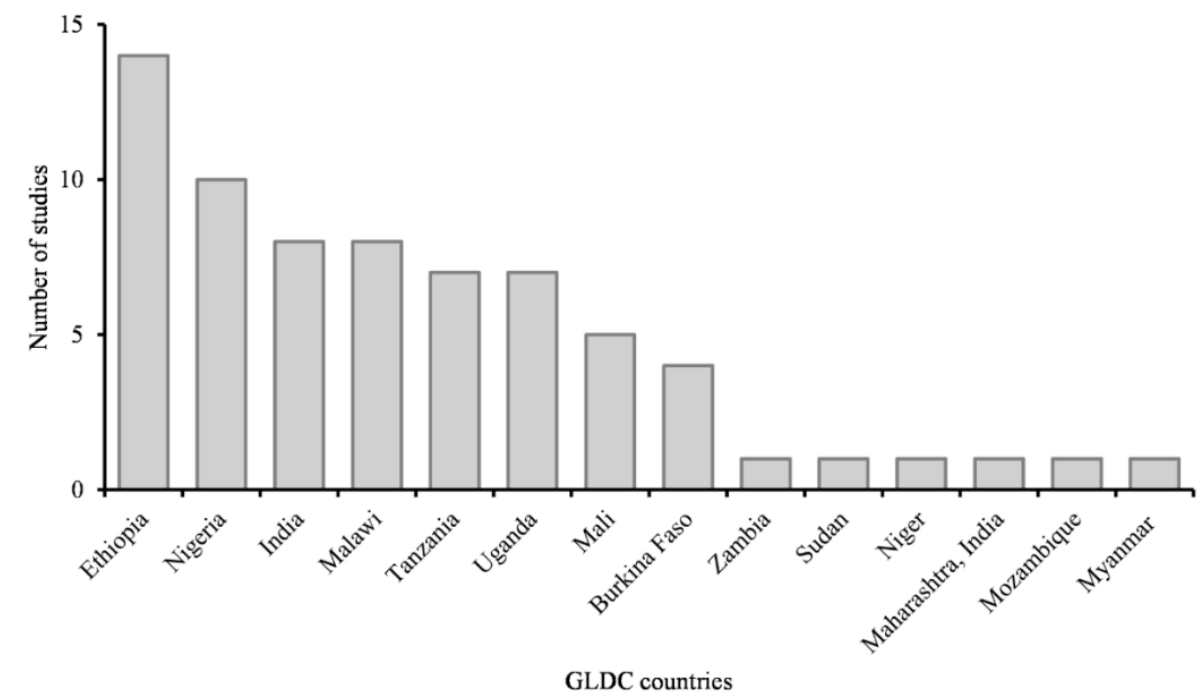

Figure 5. Number of studies by target countries

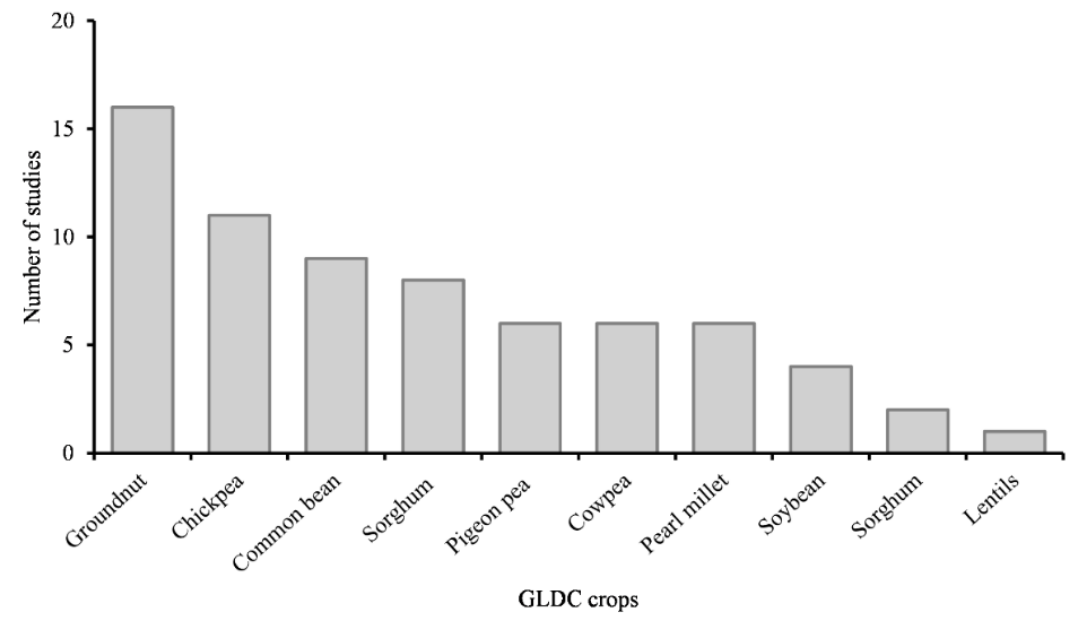

Figure 6. Studies by target GLDC crops

\subsection{National-level adoption rate estimates by target crops and country}

Figure 7 presents our updated 2019 CCC adoption rate estimates, defined as a percentage of national cropping area (Step 2 in Figure 1). There is large variation across the crops and countries, ranging from as low as $7 \%$ for improved millet varieties in Burkina Faso to nearly $100 \%$ for chickpea in Myanmar. We indicate which adoption rate estimates are informed by higher confidence studies (i.e., survey data $\left.{ }^{(*)}\right)$ ) and those informed by lower confidence studies (i.e., expert opinion $\left(^{*}\right)$ ). 


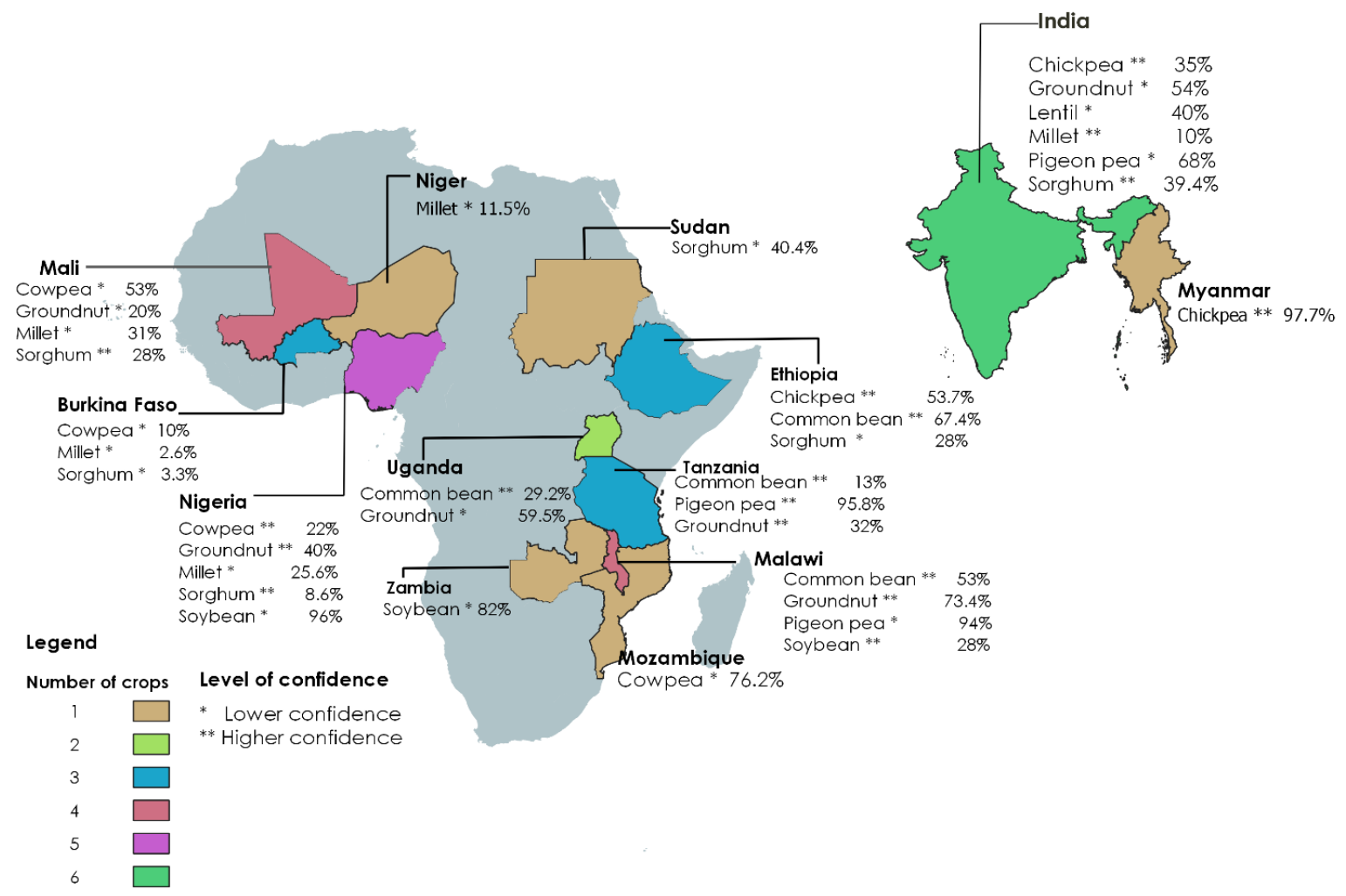

Figure 7. Updated national adoption rate in $\mathbf{2 0 1 9}$ (\% area) by target countries and crops

From data associated with both the higher and lower confidence studies, we estimate that the adoption rate of GLDC improved varieties has increased considerably over the 2011 to 2019 period (Table 2). On average, we estimate that there was an increase from $37 \%$ to $52 \%$ for all studies and $30 \%$ to $46 \%$ for the higher confidence studies. This $15-$ $16 \%$ increase in the adoption rate varies across the GLDC crop portfolio. However, there is considerable variation across individual CCCs, ranging from as high as $46 \%$ for pigeon pea to as low as $3 \%$ for soya bean. 
Table 2. Overall average adoption rate (\% of national cropping area) by GLDC target crop

\begin{tabular}{|c|c|c|c|c|c|c|}
\hline \multirow[b]{2}{*}{ Crop } & \multicolumn{6}{|c|}{2011 estimates $(\%$} \\
\hline & All studies & HC studies & All studies & HC studies & $\begin{array}{c}\text { All } \\
\text { studies } \\
\end{array}$ & HC studies \\
\hline \multicolumn{7}{|l|}{ Grain legumes } \\
\hline Chickpea & $\begin{array}{l}\text { Ethiopia, India, } \\
\text { Myanmar }\end{array}$ & $\begin{array}{l}\text { Ethiopia, India, } \\
\text { Myanmar }\end{array}$ & 34 & 34 & 63 & 63 \\
\hline Common bean & $\begin{array}{l}\text { Ethiopia, Malawi, } \\
\text { Tanzania, Uganda }\end{array}$ & $\begin{array}{l}\text { Ethiopia, } \\
\text { Malawi, } \\
\text { Tanzania, } \\
\text { Uganda } \\
\end{array}$ & 30 & 30 & 41 & 41 \\
\hline Cowpea & $\begin{array}{l}\text { Burkina Faso, } \\
\text { Nigeria } \\
\text { Mozambique, Mali }\end{array}$ & Nigeria & 23 & 17 & 43 & 25 \\
\hline Groundnut & $\begin{array}{l}\text { India, Malawi, Mali, } \\
\text { Nigeria, Tanzania, } \\
\text { Uganda }\end{array}$ & $\begin{array}{l}\text { Malawi, Nigeria, } \\
\text { Tanzania }\end{array}$ & 38 & 33 & 55 & 50 \\
\hline Lentils & India & India & 40 & 40 & 59 & 59 \\
\hline Pigeon pea & $\begin{array}{l}\text { India, Malawi, } \\
\text { Tanzania }\end{array}$ & Tanzania & 56 & 50 & 91 & 96 \\
\hline Soybean & $\begin{array}{l}\text { Malawi, Nigeria, } \\
\text { Zambia }\end{array}$ & Malawi & 74 & 25 & 64 & 28 \\
\hline Dryland cereal & & & & & & \\
\hline Millet & $\begin{array}{l}\text { Burkina Faso, } \\
\text { India, Mali, Niger, } \\
\text { Nigeria }\end{array}$ & India, Nigeria & 16 & 18 & 22 & 22 \\
\hline Sorghum & $\begin{array}{l}\text { Burkina Faso, } \\
\text { Ethiopia, India, } \\
\text { Mali, Niger, } \\
\text { Nigeria, Sudan }\end{array}$ & $\begin{array}{l}\text { India, Mali, } \\
\text { Nigeria }\end{array}$ & 22 & 25 & 33 & 34 \\
\hline $\begin{array}{l}\text { Overall } \\
\text { average }\end{array}$ & & & 37 & 30 & 52 & 46 \\
\hline
\end{tabular}

Notes: $\mathrm{HC}=$ higher confidence

\subsection{Aggregate area under improved varieties and number of households adopted} In this section, we present our adoption estimates for both the area under improved varieties (Step 3 of Figure 1) and the number of adopting households (Step 4) by country. Estimates by target crops are presented in Appendixes D and E.

Using data from all studies, we estimate that improved GLDC varieties were planted on approximately 32 million hectares of land in 2019 in the 13 target countries (Table 3). This figure is over 15 million when only the higher confidence studies are considered. We further estimate the overall increase in area from 2011 to 2019 to be over 14 million hectares for the set of studies and nearly 7 million hectares for only the higher confidence studies. The largest gains were in the two most populous countries in CRP GLDC's portfolio, India and Nigeria. For the former, there is a considerable difference between the estimates from all studies and the higher confidence studies: 5.4 million and 2.9 million, respectively. Sudan ranks third, but we are only able to offer a lower confidence 
estimate of 2.2 million hectares. The gains in area for the remaining countries are under 1 million hectares. Ethiopia is the only country where our higher confidence estimate is negative $(-67,000 \mathrm{ha})$, driven by less area devoted to growing improved varieties of common bean (see Appendix F).

Table 3. Estimated national area under improved varieties in 2011 and 2019

\begin{tabular}{|c|c|c|c|c|c|c|}
\hline \multirow[b]{2}{*}{ Region/country } & \multicolumn{2}{|c|}{$\begin{array}{l}\text { Estimated area under IV } \\
\text { in } 2011 \text { ('000 ha) }\end{array}$} & \multicolumn{2}{|c|}{$\begin{array}{c}\text { Estimated area under IV in } \\
2019 \text { ('000 ha) }\end{array}$} & \multicolumn{2}{|c|}{$\begin{array}{l}\text { Additional area under IV } \\
\text { ('000 ha) }{ }^{\mathrm{a}}\end{array}$} \\
\hline & $\begin{array}{c}\text { Overall } \\
\text { estimates }\end{array}$ & $\begin{array}{c}\text { Higher } \\
\text { confidence }\end{array}$ & $\begin{array}{c}\text { Overall } \\
\text { estimates }\end{array}$ & $\begin{array}{c}\text { Higher } \\
\text { confidence }\end{array}$ & $\begin{array}{c}\text { Overall } \\
\text { estimates }\end{array}$ & $\begin{array}{c}\text { Higher } \\
\text { confidence }\end{array}$ \\
\hline South Asia & 10,307 & 4,786 & 15,757 & 7,782 & 5,450 & 2,996 \\
\hline India & 10,026 & 4,505 & 15,379 & 7,404 & 5,353 & 2,899 \\
\hline Myanmar & 281 & 281 & 378 & 378 & 97 & 97 \\
\hline \multicolumn{7}{|l|}{ Sub-Saharan } \\
\hline Africa & 7,566 & 3,621 & 16,251 & 7,588 & 8,685 & 3,967 \\
\hline Burkina Faso & 234 & - & 417 & - & 183 & - \\
\hline Ethiopia & 542 & 368 & 814 & 301 & 272 & -67 \\
\hline Malawi & 388 & 293 & 775 & 528 & 387 & 235 \\
\hline Mali & 954 & 372 & 1,777 & 544 & 823 & 172 \\
\hline Mozambique & 11 & - & 253 & - & 242 & - \\
\hline Niger & 834 & - & 1,222 & - & 388 & - \\
\hline Nigeria & 2,469 & 2,198 & 6,078 & 5,539 & 3,609 & 3,341 \\
\hline Sudan & 1,658 & - & 3,888 & - & 2,230 & - \\
\hline Tanzania & 302 & 302 & 518 & 518 & 216 & 216 \\
\hline Uganda & 113 & 88 & 348 & 158 & 235 & 70 \\
\hline Zambia & 61 & - & 161 & - & 100 & - \\
\hline Total & 17,874 & 8,407 & 32,008 & 15,370 & 14,135 & 6,963 \\
\hline
\end{tabular}

As explained by in Section 2, our estimation approach divides our national area estimates for each crop by its associated average household cropping area. Areas of geographic overlap in cropping areas are further identified, with only our highest single crop-specific estimates taken from these areas to adjust for potential double counting. We estimate a slightly lower but comparable increase in the overall number of households that adopted improved GLDC varieties: 12.5 million (Table 4) compared with 14.1 million hectares (Table 3). However, this same difference vis-à-vis our higher confidence estimates is considerably greater: 1.15 million households compared to 6.97 million hectares.

We find that this apparent inconsistency is driven by our estimates for India, which are considerably larger than those of the other countries. For this country, we estimate that there was an approximate 11\% drop in the numbers of households growing improved GLDC varieties overall. However, this was not necessarily due to the dis-adoption of improved varieties; indeed, the adoption growth rates are all positive for all GLDC crops 
targeted for this country (Appendix C). Rather, it is due to a significant decrease in the cropping area devoted to sorghum between the two time periods. Nationally, the area devoted to this crop dropped from 7.4 million to 4.1 million hectares over this period (Charyulu et al., 2016). This, in turn, resulted in a drop in our estimated area devoted to, as well as households cultivating, improved sorghum varieties (see Appendix $C$ and Appendix F). At the same time the adoption of other improved GLDC varieties increased considerably, notably chickpea, which we estimate to have increased by over $500 \%$ (Appendix F). While the estimated drop in households cultivating sorghum is considerably greater (2.16 million) compared to the increase in improved chickpea adopting households ( 0.55 million), the average area per household devoted the former crop is considerably less ( $0.3 \mathrm{ha})$ compared with the latter $(4.9 \mathrm{ha})$. This is why our area estimates derived from the higher confidence studies are considerably greater than are those corresponding to our household estimates.

Table 4. Number of households that had adopted improved varieties at the benchmark and updated 2019, aggregated by targeted countries

\begin{tabular}{lrrrrrr}
\hline & \multicolumn{2}{c}{$\begin{array}{c}\text { Estimated HHs 2011 } \\
\text { ('000s) }\end{array}$} & \multicolumn{2}{c}{$\begin{array}{c}\text { Estimated HHs 2019 } \\
\text { ('000s) }\end{array}$} & \multicolumn{2}{c}{ Additional HHs ('000s) } \\
\cline { 2 - 7 } Region/country & $\begin{array}{c}\text { Overall } \\
\text { estimates }\end{array}$ & $\begin{array}{c}\text { Higher } \\
\text { confidence }\end{array}$ & $\begin{array}{c}\text { Overall } \\
\text { estimates }\end{array}$ & $\begin{array}{c}\text { Higher } \\
\text { confidence }\end{array}$ & $\begin{array}{c}\text { Overall } \\
\text { estimates }\end{array}$ & $\begin{array}{c}\text { Higher } \\
\text { confidence }\end{array}$ \\
\hline South Asia & & & & & & \\
$\quad$ India & $\mathbf{2 0 , 5 5 6}$ & $\mathbf{9 , 5 1 3}$ & $\mathbf{2 4 , 4 4 8}$ & $\mathbf{8 , 4 9 9}$ & $\mathbf{3 , 8 9 2}$ & $\mathbf{- 1 , 0 1 4}$ \\
Myanmar & 20,391 & 9,348 & 24,226 & 8,277 & 3,835 & $-1,071$ \\
& 165 & 165 & 222 & 222 & 57 & 57 \\
Sub-Saharan & & & & & & \\
Africa & $\mathbf{1 1 , 5 5 9}$ & $\mathbf{6 , 9 7 6}$ & $\mathbf{2 0 , 1 8 8}$ & $\mathbf{9 , 1 4 3}$ & $\mathbf{8 , 6 2 9}$ & $\mathbf{2 , 1 6 7}$ \\
$\quad$ Burkina Faso & 272 & & 515 & & 243 & \\
Ethiopia & 592 & 437 & 1,771 & 404 & 1,172 & -33 \\
Malawi & 646 & 456 & 1,474 & 979 & 827 & 523 \\
Mali & 1,165 & 124 & 2,467 & 181 & 1,302 & 57 \\
Mozambique & 49 & & 1,148 & & 1,099 & \\
Niger & 1,668 & & 2,444 & & 776 & \\
Nigeria & 5,578 & 5,262 & 6,891 & 6,261 & 1,313 & 999 \\
Sudan & 754 & & 1,767 & & 1,013 & \\
$\quad$ Tanzania & 329 & 329 & 660 & 660 & 331 & 331 \\
$\quad$ Uganda & 374 & 368 & 702 & 658 & 328 & 290 \\
$\quad$ Zambia & 132 & & 349 & & 217 & \\
\hline Total & $\mathbf{3 2 , 1 1 5}$ & $\mathbf{1 6 , 4 8 9}$ & $\mathbf{4 4 , 6 3 6}$ & $\mathbf{1 7 , 6 4 2}$ & $\mathbf{1 2 , 5 2 1}$ & $\mathbf{1 , 1 5 3}$ \\
\hline
\end{tabular}

There are several other differences between the cropping area and household adoption estimates. For Ethiopia, Malawi, and Mozambique, our area estimates are considerably lower than those for adopting households. The main explanation is that the average household cropping area for the crops that saw the greatest expansion over the 9-year period are significantly less than 1 ha. In Malawi, for example, our estimated increase in cropping area devoted to improved groundnut varieties is 0.162 million hectares (Appendix $\mathrm{F}$, yet the average household area cultivated for this crop is only 0.3 ha (Appendix C). Hence, the estimate for households is significantly greater than it is for 
hectares (Appendix G). The same is the case for sorghum in Ethiopia and cowpea in Mozambique.

For Nigeria and to a lesser extent Sudan, the trend is the reverse; the area estimates are significantly larger than the household estimates. For Sudan, the reason is straightforward: The average household area allocated for sorghum is 2.2 ha, resulting in fewer households than hectares. For Nigeria, the situation is more complex, due to the five improved GLDC varieties with differing average household cropping area allocations - several significantly over and several significantly under 1 ha. In short, the reason the area estimates are larger is both due to a greater increase area covered by crops with an average cropping area above 1 ha and adjustments made for potential double counting.

\section{Summary and conclusion}

Arguably, GLDC is, at its core, a crop improvement program. Improved GLDC varieties have been bred to address specific needs or problems; for example, low productivity, erratic rainfall patterns, recurrent droughts, pest attacks, and emerging trends in consumer demand. These improved crop varieties are then released through national variety release systems, with the expectation that farmers will adopt them and, in turn, experience the associated benefits, particularly when complemented by other interventions, such as extension and market access support. The large-scale adoption of improved GLDC varieties is therefore a key prerequisite for program impact.

Fortunately, efforts by GLDC, its predecessor research programs, and others have invested in carrying out country specific adoption studies and other estimation approaches. Several methods have been used, most notably expert opinion solicitation, representative household-level adoption surveys, and more recently DNA fingerprinting. We capitalized on this investment by systematically searching and screening all relevant studies pertaining to the adoption of improved GLDC crop varieties in the 13 countries targeted by the program. Through this, we identified 35 unique CCCs and 69 relevant studies that target CRP GLDC CCCs.

Unfortunately, we were unable to simply combine the results of these studies to ascertain current levels of adoption. The units in which estimates are reported vary, and data collection for most studies took place several years ago in non-nationally representative survey areas. Moreover, 16 of the 35 studies relied on soliciting expert opinion as the main estimation method, which can be less reliable

Our approach addressed these issues. This involved (a) multiplying the study's adoption rate by the surveyed region's share of the national cropping area to derive a conservative estimate of the national adoption rate at the time of data collection; (b) updating a to 2019 using the average adoption growth rate for the crop in question; (c) multiplying $b$ by the national cropping area to estimate of the area the improved variety in 2019; and (d) dividing $c$ into the average cultivated area per household for the crop in question to derive an estimated number of households growing the improved variety in 2019 . We 
further mitigated the potential for double counting at the household level by conservatively informing our overall household adoption estimates with the highest cropspecific estimates in overlapping national cropping areas. Finally, we treated estimates derived from studies based on household surveys and expert opinion with higher and lower levels of confidence, respectively, thereby generating both overall and higher confidence estimates.

From this, we estimate from both the higher and lower confidence studies that the area under improved GLDC varieties increased by approximately $15 \%$ on average across the 13 targeted countries between 2011 and 2019. As of 2019, we estimate from the higher confidence studies that improved GLDC crops were cultivated on 15.37 million hectares of land across 17.64 million households in these same countries. When we include the lower confidence studies, these estimates increase to 32 million hectares and 44.64 million households.

The gain in both area and household-level adoption from 2011 is also significant, but less so for our estimates based on household survey data. From the higher confidence studies, we estimate the gains in cropping area under improved GLDC varieties to be 6.96 million hectares. With the inclusion of lower confidence estimates, this rises to 14.13 million hectares. Our estimates from only the higher confidence studies for the number of adopting households is far lower, standing at 1.53 million. This is primarily driven by a significant reduction in the overall sorghum cropping area in India, but this is not indicative of a drop in the adoption rate of this crop or any other.

With the inclusion of expert opinion-based studies, our estimates of additional households adopting improved GLDC varieties increases considerably to 12.5 million. This estimate exceeds CRP GLDC's adoption target (8.9 million households) by over $40 \%$. Hence, we can be reasonably confident that the program at least met this target, as there would need to be considerable upwards bias among the 16 of the 35 studies relying on expert opinion solicitation and/or our overall estimation approach for this to be otherwise.

Moreover, if we consider likely spillovers of improved GLDC varieties to (a) non-surveyed areas in priority GLDC countries and (b) non-priority countries but where scaling efforts have taken place (e.g., Bangladesh), as well as (c) the diffusion of non-priority GLDC varieties in priority countries (e.g., groundnuts in Zambia and Kenya), our confidence only grows. For example, Mausch et al. (2013) highlight improved groundnut varieties are high adaptable and have diffused far beyond the areas and countries where they were initially released. Similar results have been highlighted for sorghum (Charyulu et al., 2014).

In addition, our approach addresses the potential of double counting by taking only the highest adoption estimate in potential areas of overlap, thereby assuming adopting households adopted all improved varieties in question. In reality, it is unlikely that all households adopted the full set of improved crop varieties in these areas of geographic 
overlap, thereby resulting in an underestimation of the total number of adopting households.

Despite our confidence that GLDC's overall household adoption target has likely been significantly exceeded, we cannot confidently say by how much; there are too many factors that prevent us from providing precise estimates. We therefore conclude by making three recommendations on how such adoption estimation can be improved. First, continued efforts should be made to improve the accuracy of such estimates. While adoption surveys are likely (at least in general) preferable to soliciting expert opinion, recent studies comparing results obtained from farmer self-reporting and DNA analysis of seed samples obtained from farmers' fields reveal high levels of inconsistency with respect to the former (cf. Jaleta et al., 2020; Maredia et al., 2016). DNA fingerprinting is the only reliable identification method for many crops (Milne et al., 2015).

A second area of improvement is to the frequency of adoption-related surveys. As highlighted above, only 4 of our 35 shortlisted studies are based on data collected from 2018 onwards. This required us to compute adoption growth rates to generate more upto-date estimates, another potential source of measurement error, given that the average adoption growth rate may vary year by year. Of course, increasing the frequency of adoption-related surveys will increase costs and, therefore, may not be always financially viable. However, recent efforts to include indicators in large-scale efforts, such as the World Bank's Living Standard Measurement Survey, could prove valuable in gaining a deeper and broader understanding of adoption dynamics at a more granular level (Kosmowski et al., 2020).

This leads us to our third and final recommendation: explore ways of increasing the efficiency of reliable adoption estimation approaches. Here, we recommend innovatively integrating such surveys as part of project-related monitoring, evaluation strategies, and even trait-demand appraisal exercises, alongside scaling up efforts to 'piggy back' on nationally representative data collection exercises (Macours et al. 2021). 


\section{References}

Ahmed, B., Echekwu, C.A., Mohammed, S.G., Ojiewo, C., Ajeigbe, H., Vabi, M.B., Affognon, H., Lokossou, J., Nwahia, O.C., 2020. Analysis of Adoption of Improved Groundnut Varieties in the Tropical Legume Project (TL III) States in Nigeria. Agricultural Sciences 11, 143-156. https://doi.org/10.4236/as.2020.112009

Amponsah, K., Paliwal, N., 2015. Technology and managerial gaps in the adoption of improved groundnut varieties in Malawi and Uganda. Selected Paper prepared for presentation at the 2015 Agricultural \& Applied Economics Association and Western Agricultural Economics Association Annual Meeting, July 26-28, San Francisco, California, p. 29.

Bantilan, C., Charyulu, K.D., Gaur, P.M., Shyam, M.D., Davis, J., 2014. Short-duration chickpea technology: eneabling legumes revolution in Andhra Pradesh, India, Research Report No. 23 Patancheru 502 324. Telangana, India: International Crops Research Institute for the Semi-Arid Tropics. 208 pp.

Boughton, D., Makhija, S., Maredia, M., Mather, D., Megill, D., Ortega, D.L., Payongayong, E., Plataroti, L., Spielman, D.J., Thijssen, M., Win, M.T., 2020. Variety adoption and demand for quality seed in the Central Dry Zone of Myanmar. Food Security Policy Research Paper 118.

Bushara, M.O. A, Abuagala, MM. 2016. Measuring Production Efficiency of Sorghum Small Farmers in Rahad Agricultural Scheme Season (2011-2012). Journal of Socialomics 5: 19. doi:10.41 72/2167-0358.1000192

Cavatassi, R., Lipper, L., Narloch, U., 2011. Modern variety adoption and risk management in drought prone areas: insights from the sorghum farmers of eastern Ethiopia. Agricultural Economics 42, 279-292.

Charyulu, D., Bantilan, M.C.S., Reddy, B.V.S., Kumar, A.A., Ahmed, I., Davis, J., 2014. Estimation of ICRISAT Sorghum Research Spillover benefits - Strategies for Research Prioritization. Research Report No 72. Research Program Asia, Patancheru 502324. Telangana, India: International Crops Research Institute for the Semi-Arid Tropics. 64 pp. ISBN 978-92-9066-582-3

Charyulu, D.K., Shyam, D.M., Bantilan, C., Borikar, S.T., Kumar, A.A., Reddy, B.V.S., 2016. Rainy Season Sorghum Technology Adoption and Impact Study in Maharashtra. Research Report 70 (Technical Report). ICRISAT, Patancheru, Telangana, India.

Charyulu, K., Shyam, D.M., Bantilan, C., Borikar, S.T., Gupta, S.K., Rai, K.N., 2017. Pearl Millet Technology Adoption and Impact Study in Maharashtra, Research Report No 71. ICRISAT, Patancheru, Telangana, India.

Dalton, T.J., Regier, G., 2016. Impact assessment report Non.1. Assessment of the impact of improved pigeon pea development in northern Tanzania. Patancheru 502 324, Telangana, India: International Crops Research Institute for the Semi-Arid Tropics. 52 pp.

FAO, 2020. FAOSTAT Database. FAO, Rome, Italy.

ICRISAT, 2020. 304 improved varieties developed in 15 countries in Africa, Bangladesh and India. p. 1.

ICRISAT, n.d. Sorghum| EXPLOREit@ICRISAT. URL http://exploreit.icrisat.org/profile/Sorghum/193 (last accessed 6.3.21).

Jaleta, M., Tesfaye, K., Kilian, A., Yirga, C., Habte, E., Beyene, H., Abeyo, B., Badebo, A., Erenstein, O., 2020. Misidentification by farmers of the crop varieties they grow: Lessons from DNA fingerprinting of wheat in Ethiopia. PLoS ONE 15, e0235484. https://doi.org/10.1371/journal.pone.0235484 
Joseph, B.B., Leandre, P.S., Silamana, B., Evelyne, C., Hamadou, Z., Hamadou, S., Karidiatou, G., Adelaide, S.O., James, N.B., 2021. Cowpea Innovation Platform Interventions and Achievements in TL III Project in Burkina Faso, in: Akpo, E., Ojiewo, C.O., Kapran, I., Omoigui, L.O., Diama, A., Varshney, R.K. (Eds.), Enhancing Smallholder Farmers' Access to Seed of Improved Legume Varieties Through Multi-Stakeholder Platforms: Learning from the TLIII Project Experiences in Sub-Saharan Africa and South Asia. Singapore Springer, pp. 157-170. https://doi.org/10.1007/978-981-15-8014-7_11

Kamara, A., Kamai, N., Kanampiu, F., Reuben, A., Jajua, M., Kadafur, I.M., 2018. The adoption of soybean in northern Nigeria: the case of Kaduna state 48. IITA, Ibadan, Nigeria. ISBN 978-978-131-359-2. 37 pp.

Katungi, E., Farrow, A., Mutuoki, T., Gebeyehu, S., Karanja, D., Alamayehu, F., Sperling, L., Beebe, S., Rubyogo, J.C., Buruchara, R., 2010. Improving common bean productivity: An Analysis of socioeconomic factors in Ethiopia and Eastern Kenya. Baseline Report Tropical legumes II. Centro Internacional de Agricultura Tropical-CIAT. Cali, Colombia.

Katungi, E., Letaa, E., Kabungo, C., Mukankusi, C., Raatz, B., Ssekamate, A., Rubyogo, C., 2019. Assessing the impact of the tropical legumes II\& III project on common bean productivity, profitability and marketed surplus in southern highlands of Tanzania. Technical Report. Tanzania. 48 p.

Katungi, E., Ruth Magreta, Emmanuel Letaa, Rowland Chirwa, Kelvin Dambuleni and Sospeter Nyamwaro, 2017. Adoption and impact of improved bean varieties on food security in Malawi. International Center for Tropical Agriculture (CIAT); Pan-Africa Bean Research Allience (PABRA). 45 p. https://doi.org/10.13140/rg.2.2.27281.94562

Kosmowski, F., Alemu, S., Mallia, P., Stevenson, J., Macours, K., 2020. Shining a Brighter Light: Comprehensive Evidence on Adoption and Diffusion of CGIAR-Related Innovations in Ethiopia. Rome: Standing Panel on Impact Assessment (SPIA).

Kouyate, Z., Dao, K.M., Togola, O., Malle, A.K., Malle, O., Diakite, K., Traore, A., 2021. Cowpea Seed Innovation Platform: A Hope for Small Seed Producers in Mali.In Akpo, E., Ojiewo, C.O., Kapran, I., Omoigui, L.O., Diama, A., Varshney, R.K. eds. Enhancing Smallholder Farmers' Access to Seed of Improved Legume Varieties Through Multi-Stakeholder Platforms: Learning from the TLIII Project Experiences in Sub-Saharan Africa and South Asia. Singapore: Springer, pp. 143-156. https://doi.org/10.1007/978-981-15-80147_10

Larochelle, C., Alwang, J., Norton, G.W., Katungi, E., Labarta, R.A., 2015. Impacts of improved bean varieties on poverty and food security in Uganda and Rwanda. In Walker, T.S., Alwang, J. eds. Crop Improvement, Adoption, and Impact of Improved Varieties in Food Crops in Sub-Saharan Africa. Wallingford, UK: CABI, pp. 314-337. https://doi.org/10.1079/9781780644011.0314

Macours, K., Kosmowski, F., Alemu, S., Mallia, P., Stevenson, J., 2021. Shining a brighter light: Datadriven evidence on adoption and diffusion of agricultural innovations in Ethiopia. World Bank Webinar, January $21^{\text {st }}, 2021$, Online.

Manda, J., Alene, A.D., Tufa, A.H., Abdoulaye, T., Wossen, T., Chikoye, D., Manyong, V., 2019. The poverty impacts of improved cowpea varieties in Nigeria: A counterfactual analysis. World Development 122, 261-271. https://doi.org/10.1016/j.worlddev.2019.05.027

Maredia, M.K., Reyes, B.A., Manu-Aduening, J., Dankyi, A., Hamazakaza, P., Muimui, K., Rabbi, I., Kulakow, P., Parkes, E., Abdoulaye, T., Katungi, E., Raatz, B., 2016. Testing Alternative Methods of Varietal Identification Using DNA Fingerprinting: Results of Pilot Studies in Ghana and Zambia. Food Security International Development Working Papers, No. 246950. East Lansing, Michigan 48824-1039, U.S.A. Michigan State University, Department of Agricultural, Food, and Resource Economics. 
Mausch, K., Chiwaula, L., Irshad, A., Bantilan, C., Silim, S., Siambi, M., 2013. Strategic Breeding Investments for Legume Expansion: Lessons Learned from the Comparison of Groundnut and Pigeonpea. Contributed paper prepared for presentation at the 57th AARES Annual Conference, 5th-8th February 2013, Sydney, New South Wales.

Milne, S., Rao, N.V.P.R.G., Orr, A., 2015. How Accurate are Adoption Rates? Testing a Protocol for Pigeon pea in northern Tanzania. ICRISAT Socioeconomics Discussion Paper Series 30. Patancheru 502 324. Telangana, India: International Crops Research Institute for the Semi-Arid Tropics. http://oar.icrisat.org/id/eprint/8586.

Monyo, E., Varshney, R.K. eds. 2016. Seven seasons of learning and engaging smallholder farmers in the drought-prone areas of sub-Saharan Africa and South Asia through Tropical Legumes, 2007-2014.Telangana, India: International Crops Research Institute for the Semi-Arid Tropics. ISBN 978-92-9066-568-7. 236 pp.

Mwakimata, R.G., 2018. Gendered yield gap analysis in groundnut production in Tanzania: social and economic implications. Master's Thesis. Morogoro, Tanzania: Sokoine University of Agriculture.

Ndjeunga, J., Umar, J., Ahmed, B., Aba, A., Ibro, A., Abdoulaye, A., Gwadi, K., 2011. Adoption and impacts of modern sorghum and pearl millet varieties in Northern Nigeria. Working Paper. International Crops Research Institute for the Semi-Arid Tropics. (Unpublished)

Pachico, D., 2014. Towards appraising the impact of legume research: A synthesis of evidence. Rome, Italy, Standing Panel on Impact Assessment (SPIA), CGIAR Independent Science and Partnership Council (ISPC). 39 pp.

Shiferaw, B., Muricho, G., Okello, J., Kebede, T.A., Okecho, G., 2010. Adoption of Improved Groundnut Varieties in Uganda. Research Report no. 5. Patancheru 502 324, Andhra Pradesh, India: International Crops Research Institute for the Semi-Arid Tropics. 36 pp. URL http://oar.icrisat.org/227/.

Smale, M., Kergna, A.O., Assima, A., Weltzien, E., Rattunde, F., 2014. An Overview and Economic Assessment of Sorghum Improvement in Mali. MSU International Development Working Paper, No. 137. East Lansing, Michigan, U.S.A. Michigan State University, Department of Agricultural, Food, and Resource Economics. https://doi.org/10.22004/ag.econ.198186

TechnoServe, 2010. Southern Africa Soy Roadmap - Zambai value chain analysis. November 2010 -February 201. Power point presentation. Accessed at https://www.technoserve.org/wp-content/uploads/2013/02/technoserve-bmgf-southafrica.pdf.

Tripp, R., 2011. The Impacts of Food Legume Research in the CGIAR: A Scoping Study. Rome, Italy, Standing Panel on Impact Assessment (SPIA), CGIAR Independent Science and Partnership Council (ISPC) (available at http://impact.cgiar.org/sites/default/files/images/ LegumeScoping2011.pdf).

Tufa, A.H., Alene, A.D., Manda, J., Akinwale, M.G., Chikoye, D., Feleke, S., Wossen, T., Manyong, V., 2019. The productivity and income effects of adoption of improved soybean varieties and agronomic practices in Malawi. World Development 124, 104631. https://doi.org/10.1016/j.worlddev.2019.104631

USAID. 2016. Mozambique agricultural value chain analysis. LEO report, No. 31. Accessed at http://www.acdivoca.org/wp-content/uploads/2016/09/Report-No31-Mozambique-VCA-

Report.pdf

Varshney, R.K., Ojiewo, C.O., Monyo, E., 2019. A decade of Tropical Legumes projects: Development and adoption of improved varieties, creation of market-demand to benefit smallholder farmers and empowerment of national programmes in sub-Saharan Africa and South Asia. Plant Breeding.138: 379-388. DOI: 10.1111/pbr.12744 
Verkaart, S., Mausch, K., Claessens, L., Giller, K.E., 2018. A recipe for success? Learning from the rapid adoption of improved chickpea varieties in Ethiopia. International Journal of Agricultural Sustainability. 17: 34-48.

Walker, T.S., 2015. Validating adoption estimates generated by expert opinion and assessing the reliability of adoption estimates with different methods. In Walker, T.S., Alwang, J. eds. Crop Improvement, Adoption, and Impact of Improved Varieties in Food Crops in Sub-Saharan Africa. Wallingford, U: CABI, pp. 406-419. https://doi.org/10.1079/9781780644011.0406

Walker, T.S., Alwang, J. eds. 2015. Crop improvement, adoption, and impact of improved varieties in food crops in sub-Saharan Africa. Wallingford, UK: CABI, https://doi.org/10.1079/9781780644011.0000 


\section{Appendix A: National area under GLDC crops in the baseline and 2019 based on}

FAOSTAT database

\begin{tabular}{|c|c|c|c|}
\hline Country & Crop & $\begin{array}{l}\text { National crop area at the } \\
\text { benchmark ('0000 ha) }\end{array}$ & $\begin{array}{c}\text { National area in } 2019 \\
\text { ('0000 ha) }\end{array}$ \\
\hline Ethiopia & Chickpea & 240 & 209 \\
\hline India & Chickpea & 8,522 & 9,547 \\
\hline Myanmar & Chickpea & 333 & 380 \\
\hline Ethiopia & Common bean & 583 & 281 \\
\hline Malawi & Common bean & 307 & 349 \\
\hline Tanzania & Common bean & 738 & 894 \\
\hline Uganda & Common bean & 669 & 540 \\
\hline Burkina Faso & Cowpea & 1,332 & 1,354 \\
\hline Mali & Cowpea & 239 & 454 \\
\hline Mozambique & Cowpea & 99 & 331 \\
\hline Nigeria & Cowpea & 2,860 & 4,303 \\
\hline India & Groundnut & 5,860 & 4,731 \\
\hline Malawi & Groundnut & 308 & 400 \\
\hline Mali & Groundnut & 337 & 452 \\
\hline Nigeria & Groundnut & 2,354 & 4,303 \\
\hline Tanzania & Groundnut & 482 & 990 \\
\hline Uganda & Groundnut & 45 & 320 \\
\hline India & Lentils & 1,341 & 1,363 \\
\hline Burkina Faso & Millet & 1,362 & 1,177 \\
\hline India & Millet & 9,179 & 8,450 \\
\hline Mali & Millet & 1,257 & 1,990 \\
\hline Niger & Millet & 7,253 & 6,831 \\
\hline Nigeria & Millet & 4,364 & 4,303 \\
\hline India & Pigeon pea & 3,466 & 4,550 \\
\hline Malawi & Pigeon pea & 190 & 263 \\
\hline Tanzania & Pigeon pea & 257 & 87 \\
\hline Burkina Faso & Sorghum & 1,983 & 1,890 \\
\hline Ethiopia & Sorghum & 1,835 & 1,828 \\
\hline India & Sorghum & 6,210 & 4,093 \\
\hline Mali & Sorghum & 1,329 & 1,501 \\
\hline Nigeria & Sorghum & 2,860 & 5,397 \\
\hline Sudan & Sorghum & 4,103 & 6,828 \\
\hline Malawi & Soybean & 75 & 180 \\
\hline Nigeria & Soybean & 282 & 656 \\
\hline Zambia & Soybean & 61 & 196 \\
\hline
\end{tabular}


Appendix B: List of 35 adoption evidence with their level of confidence, by crop and country

\begin{tabular}{|c|c|c|c|c|}
\hline Crop & Country & Year data ascertained & Method & $\begin{array}{c}\text { Level of } \\
\text { confidence }\end{array}$ \\
\hline Chickpea & Ethiopia & 2018 & Household survey & High \\
\hline Chickpea & India & 2013 & Household survey & High \\
\hline Chickpea & Myanmar & 2018 & Household survey & High \\
\hline Common bean & Ethiopia & 2016 & Household survey & High \\
\hline Common bean & Malawi & 2013 & Household survey & High \\
\hline Common bean & Uganda & 2012 & Household survey & High \\
\hline Common bean & Tanzania & 2016 & Household survey & High \\
\hline Cowpea & Nigeria & 2017 & Household survey & High \\
\hline Cowpea & Burkina Faso & 2010 & Expert opinion & Low \\
\hline Cowpea & Mali & 2010 & Expert opinion & Low \\
\hline Cowpea & Mozambique & 2010 & Expert opinion & Low \\
\hline Groundnut & Malawi & 2011 & Household survey & High \\
\hline Groundnut & Nigeria & 2017 & Household survey & High \\
\hline Groundnut & Tanzania & 2016 & Household survey & High \\
\hline Groundnut & India & 2010 & Expert opinion & Low \\
\hline Groundnut & Mali & 2010 & Expert opinion & Low \\
\hline Groundnut & Uganda & 2010 & Expert opinion & Low \\
\hline Lentils & India & 2014 & Mixed & High \\
\hline Millet & India & 2013 & Household survey & High \\
\hline Millet & Nigeria & 2020 & Household survey & High \\
\hline Millet & Burkina Faso & 2010 & Expert opinion & Low \\
\hline Millet & Mali & 2010 & Expert opinion & Low \\
\hline Millet & Niger & 2010 & Expert opinion & Low \\
\hline Pigeon pea & Tanzania & 2012 & Household survey & High \\
\hline Pigeon pea & India & 2010 & Expert opinion & Low \\
\hline Pigeon pea & Malawi & 2010 & Expert opinion & Low \\
\hline Sorghum & Nigeria & 2010 & Household survey & High \\
\hline Sorghum & India & 2013 & Household survey & High \\
\hline Sorghum & Mali & 2013 & Household survey & High \\
\hline Sorghum & Burkina Faso & 2010 & Expert opinion & Low \\
\hline Sorghum & Ethiopia & 2014 & Expert opinion & Low \\
\hline Sorghum & Sudan & 2009 & Expert opinion & Low \\
\hline Soybean & Malawi & 2017 & Household survey & High \\
\hline Soybean & Nigeria & 2009 & Expert opinion & Low \\
\hline Soybean & Zambia & 2010 & Expert opinion & Low \\
\hline
\end{tabular}


Appendix C: Parameters used for the calculations: Average crop area per households (ha) and adoption growth rate per year

\begin{tabular}{|c|c|c|c|c|c|}
\hline Country & Crop & $\begin{array}{c}\text { Avg. } \\
\text { crop } \\
\text { area (ha) }\end{array}$ & Source & $\begin{array}{l}\text { Avg. adoption } \\
\text { growth } \\
\text { rate/year }\end{array}$ & $\begin{array}{c}\text { Adoption } \\
\text { growth rate } \\
\text { based on } \\
\text { FAOSTAT } \\
\text { yield change }\end{array}$ \\
\hline Ethiopia & Chickpea & 0.51 & Verkaart et al. (2018) & 5.9 & 3.5 \\
\hline India & Chickpea & 4.90 & Bantilan et al.(2014) & 4.6 & 1.8 \\
\hline Myanmar & Chickpea & 1.70 & Boughton et al.(2020) & 1.9 & -0.5 \\
\hline Ethiopia & $\begin{array}{l}\text { Common } \\
\text { bean }\end{array}$ & 0.87 & Katungi et al.(2010) & 1.1 & 7.0 \\
\hline Malawi & $\begin{array}{l}\text { Common } \\
\text { bean }\end{array}$ & 0.31 & Katungi et al. (2017) & & 1.1 \\
\hline Tanzania & $\begin{array}{l}\text { Common } \\
\text { bean }\end{array}$ & 0.60 & Katungi et al.(2019) & 1.3 & 7.5 \\
\hline Uganda & $\begin{array}{l}\text { Common } \\
\text { bean }\end{array}$ & 0.24 & Larochelle et al.(2015) & & 2.3 \\
\hline Burkina Faso & Cowpea & 0.9 & Joseph et al. (2021) & & 0.3 \\
\hline Mali & Cowpea & 0.5 & Kouyate et al. (2021) & & 0.4 \\
\hline Mozambique & Cowpea & 0.2 & USAID (2016) & & 7.2 \\
\hline Nigeria & Cowpea & 1.6 & Manda et al. (2019) & & 4.0 \\
\hline India & Groundnut & 0.5 & * & & 3.7 \\
\hline Malawi & Groundnut & 0.3 & $\begin{array}{l}\text { Amponsah and Paliwal } \\
\text { (2015) }\end{array}$ & 3.8 & -0.3 \\
\hline Mali & Groundnut & 0.5 & * & & 1.7 \\
\hline Nigeria & Groundnut & 1.9 & Ahmed et al. (2020) & 2.5 & -0.8 \\
\hline Tanzania & Groundnut & 0.80 & Mwakimata (2018) & 5.3 & -0.3 \\
\hline Uganda & Groundnut & 4.3 & Shiferaw et al. (2010) & 0.5 & -3.0 \\
\hline India & Lentil & 0.5 & * & & 3.8 \\
\hline Burkina Faso & Millet & 0.5 & * & & 0.5 \\
\hline India & Millet & 0.8 & Charyulu et al. (2017) & & 1.3 \\
\hline Mali & Millet & 0.5 & * & & 1.1 \\
\hline Niger & Millet & 0.5 & * & & 0.7 \\
\hline Nigeria & Millet & 0.2 & Ndjeunga et al. (2011) & 3.0 & 4.8 \\
\hline India & Pigeon pea & 0.5 & * & & 1.8 \\
\hline Malawi & Pigeon pea & 0.5 & * & & 4.9 \\
\hline Tanzania & Pigeon pea & 1.3 & Dalton and Regier (2016) & 6.6 & 2.2 \\
\hline Burkina Faso & Sorghum & 0.5 & * & & 0.6 \\
\hline Ethiopia & Sorghum & 0.3 & Cavatassi et al. (2011) & & 3.7 \\
\hline India & Sorghum & 0.3 & Charyulu et al.(2016) & & 0.8 \\
\hline Mali & Sorghum & 3.0 & Smale et al. (2014) & 1.4 & 2.0 \\
\hline Nigeria & Sorghum & 0.2 & Ndjeunga et al. (2011) & & 1.5 \\
\hline Sudan & Sorghum & 2.2 & Bushara (2016) & & 2.1 \\
\hline Nigeria & Soybean & 0.3 & Tufa et al. (2019) & & -1.4 \\
\hline Zambia & Soybean & 0.9 & Kamara et al.(2018) & & -2.0 \\
\hline Malawi & Soybean & 0.5 & TechnoServe (2010) & & 0.4 \\
\hline
\end{tabular}

Note: For observation with at least two sets of survey data, this is used to calculate adoption growth rate while we used average yield change over the last decade based on FAOSTAT data as proxy for adoption growth rate for the remaining observations. * For crops with no information on average area allocated, 0.5 ha is assumed. 
Appendix D: National area and area under improved varieties at the benchmark and updated 2019 for the whole observation, aggregated by targeted crops

\begin{tabular}{lcccrc}
\hline Crop & $\begin{array}{c}\text { Benchmark } \\
\text { national crop } \\
\text { area ('000 ha) }\end{array}$ & $\begin{array}{c}\text { Benchmark } \\
\text { area under IV } \\
\text { ('000 ha) }\end{array}$ & $\begin{array}{c}\text { National crop } \\
\text { area in 2019 } \\
\text { ('000 ha) }\end{array}$ & $\begin{array}{c}\text { Area under IV } \\
\text { in 2019 ('000 } \\
\text { ha) }\end{array}$ & $\begin{array}{c}\text { Additional } \\
\text { area under IV } \\
\text { ('000 ha) }\end{array}$ \\
\hline Dryland cereals & $\mathbf{4 1 , 7 3 5}$ & $\mathbf{8 , 2 2 9}$ & $\mathbf{4 4 , 2 8 7}$ & $\mathbf{1 2 , 8 3 2}$ & $\mathbf{3 , 9 8 8}$ \\
Millet & 23,415 & 3,268 & 22,750 & 4,714 & 1,360 \\
Sorghum & 18,320 & 4,961 & 21,537 & 8,118 & 2,627 \\
Grain legumes & $\mathbf{3 0 , 9 8 0}$ & $\mathbf{9 , 9 1 3}$ & $\mathbf{3 7 , 1 3 3}$ & $\mathbf{1 8 , 9 4 4}$ & $\mathbf{7 , 1 5 6}$ \\
Chickpea & 9,095 & 914 & 10,135 & 3,772 & 2,750 \\
Common bean & 2,297 & 590 & 2,063 & 648 & 228 \\
Cowpea & 4,530 & 757 & 6,443 & 1,762 & 618 \\
Groundnut & 9,386 & 4,129 & 11,196 & 7,033 & 2,651 \\
Pigeon pea & 3,914 & 2,580 & 4,900 & 4,175 & 907 \\
Soybean & 418 & 407 & 1,033 & 750 & -256 \\
Lentils & 1,341 & 536 & 1,363 & 804 & 259 \\
\hline Total & $\mathbf{7 2 , 7 1 5}$ & $\mathbf{1 8 , 1 4 2}$ & $\mathbf{8 1 , 4 2 0}$ & $\mathbf{3 1 , 7 7 6}$ & $\mathbf{1 1 , 1 4 3}$ \\
\hline
\end{tabular}

Appendix E: Number of households adopted improved varieties at the benchmark and updated 2019 based on all observations, aggregated by targeted crops

\begin{tabular}{lrrr}
\hline Crop & $\begin{array}{c}\text { Number of households } \\
\text { adopted at the benchmark }\end{array}$ & $\begin{array}{c}\text { Number of households } \\
\text { adopted in 2019 }\end{array}$ & $\begin{array}{c}\text { Additional number of } \\
\text { households adopted } \\
\text { since 2011 }\end{array}$ \\
\hline Dryland cereals & $\mathbf{1 9 , 3 8 5}$ & $\mathbf{2 6 , 2 2 7}$ & $\mathbf{7 , 9 7 5}$ \\
Millet & 8,611 & 11,091 & 2,292 \\
Sorghum & 10,774 & 15,136 & 5,683 \\
Grain legumes & $\mathbf{1 6 , 5 1 1}$ & $\mathbf{2 7 , 2 5 2}$ & $\mathbf{8 , 4 2 6}$ \\
Chickpea & 343 & 1,065 & 692 \\
Common bean & 1,249 & 1,663 & 620 \\
Cowpea & 752 & 2,529 & 1,275 \\
Groundnut & 7,405 & 10,999 & 4,146 \\
Pigeon pea & 1,073 & 8,250 & 1,764 \\
Soybean & 5,005 & 1,137 & -589 \\
Lentils & 684 & 1,608 & 518 \\
\hline Total & $\mathbf{3 5 , 8 9 6}$ & $\mathbf{5 3 , 4 7 9}$ & $\mathbf{1 6 , 4 0 1}$ \\
\hline
\end{tabular}


Appendix F: National area under improved varieties at the benchmark and updated 2019, by targeted countries and crops

\begin{tabular}{|c|c|c|c|c|}
\hline \multirow[b]{2}{*}{ Country } & \multicolumn{2}{|c|}{ Area under IV in 2011 ('000 ha) } & \multicolumn{2}{|c|}{ Area under IV in 2019 ('000 ha) } \\
\hline & Overall estimates & Higher confidence & Overall estimates & Higher confidence \\
\hline Burkina Faso & 234 & - & 417 & \\
\hline Millet & 35 & - & 79 & \\
\hline Sorghum & 65 & - & 166 & \\
\hline Cowpea & 133 & - & 172 & \\
\hline Ethiopia & 542 & 368 & 814 & 301 \\
\hline Sorghum & 174 & - & 513 & - \\
\hline Chickpea & 28 & 28 & 112 & 112 \\
\hline $\begin{array}{l}\text { Common } \\
\text { Bean }\end{array}$ & 340 & 340 & 189 & 189 \\
\hline India & 10,026 & 4,505 & 15,379 & 7,404 \\
\hline Millet & 918 & 918 & 1,493 & 1,493 \\
\hline Sorghum & 2,446 & 2,446 & 1,798 & 1,798 \\
\hline Chickpea & 605 & 605 & 3,309 & 3,309 \\
\hline Groundnut & 3,164 & - & 4,131 & - \\
\hline Pigeonpea & 2,357 & - & 3,844 & - \\
\hline Lentils & 536 & 536 & 804 & 804 \\
\hline Malawi & 388 & 293 & 775 & 528 \\
\hline $\begin{array}{l}\text { Common } \\
\text { Bean }\end{array}$ & 141 & 141 & 184 & 184 \\
\hline Groundnut & 132 & 132 & 294 & 294 \\
\hline Pigeonpea & 95 & - & 247 & - \\
\hline Soybean & 19 & 19 & 50 & 50 \\
\hline Mali & 954 & 372 & 1,777 & 544 \\
\hline Millet & 390 & - & 818 & \\
\hline Sorghum & 372 & 372 & 544 & 544 \\
\hline Cowpea & 127 & - & 258 & - \\
\hline Groundnut & 66 & - & 158 & - \\
\hline Mozambique & 11 & - & 253 & - \\
\hline Cowpea & 11 & - & 253 & - \\
\hline Myanmar & 281 & 281 & 378 & 378 \\
\hline Chickpea & 281 & 281 & 378 & 378 \\
\hline Niger & 834 & - & 1,222 & - \\
\hline Millet & 834 & - & 1,222 & - \\
\hline Nigeria & 2,469 & 2,198 & 6,078 & 5,539 \\
\hline Millet & 1,091 & 1,091 & 1,102 & 1,102 \\
\hline Sorghum & 246 & 246 & 1,210 & 1,210 \\
\hline Cowpea & 275 & 275 & 1,284 & 1,284 \\
\hline Groundnut & 587 & 587 & 1,944 & 1,944 \\
\hline Soybean & 271 & - & 539 & - \\
\hline Sudan & 1,658 & - & 3,888 & - \\
\hline Sorghum & 1,658 & - & 3,888 & - \\
\hline Tanzania & 302 & 302 & 518 & 518 \\
\hline $\begin{array}{l}\text { Common } \\
\text { Bean }\end{array}$ & 20 & 20 & 117 & 117 \\
\hline Groundnut & 154 & 154 & 317 & 317 \\
\hline Pigeonpea & 128 & 128 & 84 & 84 \\
\hline Uganda & 113 & 88 & 348 & 158 \\
\hline $\begin{array}{l}\text { Common } \\
\text { Bean }\end{array}$ & 88 & 88 & 158 & 158 \\
\hline Groundnut & 25 & - & 190 & - \\
\hline Zambia & 61 & - & 161 & - \\
\hline Soybean & 61 & - & 161 & - \\
\hline Grand Total & 17,874 & 8,407 & 32,007 & 15,370 \\
\hline
\end{tabular}


Appendix G: Number of households adopted improved varieties at the benchmark and updated 2019, by targeted countries and crops

\begin{tabular}{|c|c|c|c|c|}
\hline \multirow[b]{2}{*}{ Country } & \multicolumn{2}{|c|}{ Number of adopting $\mathrm{HH}$ at Benchmark } & \multicolumn{2}{|c|}{ Number of adopting HHs in 2019} \\
\hline & Overall estimates & Higher confidence & Overall estimates & Higher confidence \\
\hline Burkina Faso & 272 & - & 515 & - \\
\hline Cowpea & 141 & - & 183 & - \\
\hline Millet & $71^{\not \subset}$ & - & $157^{\not \subset}$ & - \\
\hline Sorghum & $131 \subset$ & - & $332 \subset$ & - \\
\hline Ethiopia & 591 & 437 & 1,771 & 405 \\
\hline Chickpea & 46 & 46 & 168 & 187 \\
\hline Common bean & $391^{\not \subset}$ & 391 & $218^{\not \subset}$ & 218 \\
\hline Sorghum & $545 \subset$ & - & $1,603 c$ & - \\
\hline India & 20,391 & 9,348 & 24,226 & 8,277 \\
\hline Chickpea & 123 & 123 & 675 & 675 \\
\hline Groundnut & 6,329 & - & 8,261 & - \\
\hline Millet & $1,133^{\not \subset}$ & $1,133^{\not \subset}$ & $1,844^{\not \subset}$ & $1,844^{\not}$ \\
\hline Pigeon pea & 4,714 & - & 7,688 & - \\
\hline Sorghum & $8,152 \subset$ & $8,152^{\complement}$ & 5,993 & $5,993 \subset$ \\
\hline Lentils & 1,073 & 1,073 & 1,608 & 1,608 \\
\hline Malawi & 646 & 456 & 1,473 & 979 \\
\hline Common bean & $4566^{c}$ & $456 \subset$ & $593^{\not}$ & $593^{\not \subset}$ \\
\hline Groundnut & $442^{\not \subset}$ & $442^{\not \subset}$ & 979 & $979 \subset$ \\
\hline Pigeon pea & 190 & - & 495 & - \\
\hline Soybean & $235^{\not}$ & $59 \not$ & $157^{\not}$ & $157^{\not \subset}$ \\
\hline Mali & 1,165 & 124 & 2,467 & 181 \\
\hline Cowpea & 253 & - & 515 & \\
\hline Groundnut & 132 & - & 315 & \\
\hline Millet & $779 c$ & - & $1,636 \subset$ & \\
\hline Sorghum & $124 \not \subset$ & 124 & $181^{\not \subset}$ & 181 \\
\hline Mozambique & 49 & - & 1,148 & - \\
\hline Cowpea & 49 & - & 1,148 & - \\
\hline Myanmar & 165 & 165 & 222 & 222 \\
\hline Chickpea & 165 & 165 & 222 & 222 \\
\hline Niger & 1,668 & - & 2,443 & - \\
\hline Millet & 1,668 & - & 2,443 & - \\
\hline Nigeria & 5,578 & 5,262 & 6,891 & 6,261 \\
\hline Cowpea & $174^{\not}$ & $174 \nsubseteq$ & $813^{\not}$ & $813^{\not}$ \\
\hline Groundnut & $302^{\ulcorner}$ & $302^{\ulcorner}$ & $1,002^{\subset}$ & $1,002^{\subset}$ \\
\hline Millet & 4,959 & $4,959 c$ & $5,010^{\not}$ & $5,010^{\not}$ \\
\hline Sorghum & $1,069^{\not}$ & $1,069^{\not}$ & $5,259 \subset$ & $5,259 \subset$ \\
\hline Soybean & 317 & - & 630 & - \\
\hline Sudan & 754 & - & 1,767 & - \\
\hline Sorghum & 754 & - & 1,767 & - \\
\hline Tanzania & 329 & 329 & 660 & 660 \\
\hline Common bean & 34 & 34 & 196 & 196 \\
\hline Groundnut & 194 & 194 & 398 & 398 \\
\hline Pigeon pea & 101 & 101 & 66 & 66 \\
\hline Uganda & 374 & 368 & 702 & 658 \\
\hline Common bean & 368 & 368 & 658 & 658 \\
\hline Groundnut & 6 & - & 45 & - \\
\hline Zambia & 132 & - & 349 & - \\
\hline Soybean & 132 & - & 349 & - \\
\hline Grand Total & 32,115 & 16,489 & 44,636 & 17,624 \\
\hline
\end{tabular}


Note: To mitigate potential double counting, only highest estimates maintained for country estimates where cropping areas overlap. $\subset$ denote included estimates; $\not \subset$ denote excluded estimate

Appendix H: National area and area under improved varieties at the benchmark and updated 2019 based on higher confidence evidence, aggregated by targeted crops

\begin{tabular}{lccccc}
\hline Crop & $\begin{array}{c}\text { Benchmark } \\
\text { national crop } \\
\text { area ('000 ha) }\end{array}$ & $\begin{array}{c}\text { Benchmark } \\
\text { area under IV } \\
\text { ('000 ha) }\end{array}$ & $\begin{array}{c}\text { National crop } \\
\text { area in 2019 } \\
\text { ('000 ha) }\end{array}$ & $\begin{array}{c}\text { Area under IV } \\
\text { in 2019 ('000 } \\
\text { ha) }\end{array}$ & $\begin{array}{c}\text { Additional } \\
\text { area under IV } \\
\text { ('000 ha) }\end{array}$ \\
\hline Dryland cereals & $\mathbf{2 3 , 9 4 2}$ & $\mathbf{5 , 0 7 2}$ & $\mathbf{2 3 , 7 4 4}$ & $\mathbf{6 , 1 4 7}$ & $\mathbf{1 , 7 3 0}$ \\
Millet & 13,543 & 2,009 & 12,753 & 2,596 & 675 \\
Sorghum & 10,398 & 3,064 & 10,991 & 3,551 & 1,055 \\
Grain legumes & $\mathbf{1 9 , 0 6 9}$ & $\mathbf{3 , 6 0 3}$ & $\mathbf{2 3 , 8 2 5}$ & $\mathbf{8 , 9 9 2}$ & $\mathbf{4 , 4 8 7}$ \\
Chickpea & 9,095 & 914 & 10,135 & 3,772 & 2,750 \\
Common bean & 2,297 & 590 & 2,063 & 648 & 228 \\
Cowpea & 2,860 & 486 & 4,303 & 1,080 & 348 \\
Groundnut & 3,144 & 874 & 5,693 & 2,554 & 991 \\
Pigeon pea & 257 & 128 & 87 & 84 & 40 \\
Soybean & 75 & 75 & 180 & 50 & -130 \\
Lentils & 1,341 & 536 & 1,363 & 804 & 259 \\
\hline Total & $\mathbf{4 3 , 0 1 1}$ & $\mathbf{8 , 6 7 6}$ & $\mathbf{4 7 , 5 6 8}$ & $\mathbf{1 5 , 1 3 9}$ & $\mathbf{6 , 2 1 7}$ \\
\hline
\end{tabular}


Appendix I: The benchmark, extrapolated adoption estimates and incremental change from 2010

\begin{tabular}{|c|c|c|c|c|c|c|}
\hline Country & Crop & Survey year & $\begin{array}{c}\text { National } \\
\text { adoption } \\
\text { rate } \\
\text { (\% area) }\end{array}$ & $\begin{array}{l}\text { Adoption } \\
\text { rate at the } \\
\text { benchmark }\end{array}$ & $\begin{array}{l}\text { Updated } \\
\text { adoption } \\
\text { rate in } 2019 \\
\text { (\% area) }\end{array}$ & $\begin{array}{l}\text { Change in } \\
\text { adoption } \\
\text { (\% area) }\end{array}$ \\
\hline Ethiopia & Chickpea & 2018 & 11.5 & 11.5 & 53.7 & 42.2 \\
\hline India & Chickpea & 2013 & 7.1 & 7.1 & 34.7 & 27.6 \\
\hline Myanmar & Chickpea & 2018 & 97.7 & 84.4 & 99.6 & 15.2 \\
\hline Ethiopia & Common bean & 2016 & 64.0 & 58.4 & 67.4 & 9.0 \\
\hline Malawi & Common bean & 2013 & 46.0 & 46.0 & 52.7 & 6.7 \\
\hline Tanzania & Common bean & 2016 & 9.2 & 2.7 & 13.1 & 10.4 \\
\hline Uganda & Common bean & 2012 & 13.2 & 13.2 & 29.2 & 16.0 \\
\hline Burkina Faso & Cowpea & 2010 & 10.0 & 10.0 & 12.7 & 2.7 \\
\hline Mali & Cowpea & 2010 & 53.0 & 53.0 & 56.7 & 3.7 \\
\hline Mozambique & Cowpea & 2010 & 11.0 & 11.0 & 76.2 & 65.2 \\
\hline Nigeria & Cowpea & 2017 & 21.8 & 17.0 & 25.1 & 8.1 \\
\hline India & Groundnut & 2010 & 54.0 & 54.0 & 87.3 & 33.3 \\
\hline Malawi & Groundnut & 2011 & 43.0 & 43.0 & 73.4 & 30.4 \\
\hline Mali & Groundnut & 2010 & 19.6 & 19.6 & 34.8 & 15.2 \\
\hline Nigeria & Groundnut & 2017 & 40.1 & 24.9 & 45.2 & 20.2 \\
\hline Tanzania & Groundnut & 2016 & 16.0 & 32.1 & 32.0 & -0.1 \\
\hline Uganda & Groundnut & 2010 & 55.0 & 55.0 & 59.5 & 4.5 \\
\hline India & Lentil & 2014 & 40.0 & 40.0 & 59.0 & 19.0 \\
\hline Burkina Faso & Millet & 2010 & 2.6 & 2.6 & 6.7 & 4.1 \\
\hline India & Millet & 2013 & 10.0 & 10.0 & 17.7 & 7.7 \\
\hline Mali & Millet & 2010 & 31.1 & 31.0 & 41.1 & 10.1 \\
\hline Niger & Millet & 2010 & 11.5 & 11.5 & 17.9 & 6.4 \\
\hline Nigeria & Millet & 2020 & 25.6 & 25.0 & 25.6 & 0.6 \\
\hline India & Pigeon pea & 2010 & 68.0 & 68.0 & 84.5 & 16.5 \\
\hline Malawi & Pigeon pea & 2010 & 50.0 & 50.0 & 93.9 & 43.9 \\
\hline Tanzania & Pigeon pea & 2012 & 49.6 & 49.6 & 95.8 & 46.2 \\
\hline Burkina Faso & Sorghum & 2010 & 3.3 & 3.3 & 8.8 & 5.5 \\
\hline Ethiopia & Sorghum & 2014 & 9.5 & 9.5 & 28.1 & 18.6 \\
\hline India & Sorghum & 2013 & 39.4 & 39.4 & 43.9 & 4.5 \\
\hline Mali & Sorghum & 2013 & 28.0 & 28.0 & 36.2 & 8.2 \\
\hline Nigeria & Sorghum & 2010 & 8.6 & 8.6 & 22.4 & 13.8 \\
\hline Sudan & Sorghum & 2009 & 40.4 & 40.4 & 56.9 & 16.5 \\
\hline Nigeria & Soybean & 2009 & 27.2 & 100 & 28 & -72.1 \\
\hline Zambia & Soybean & 2010 & 96.0 & 96.0 & 82.1 & -13.9 \\
\hline Malawi & Soybean & 2017 & 100.0 & 100.0 & 81.9 & -18 \\
\hline
\end{tabular}




\section{7}

252. Preferensi Petani terhadap Topik Penyuluhan dan Penyebaran Informasi Agroforestri di Indonesia http://dx.doi.org/10.5716/WP16181.PDF

253. Seri Agroforestri dan Kehutanan di Sulawesi: Keanekaragaman hayati jenis pohon pada hutan rakyat agroforestri di DAS Balangtieng, Sulawesi Selatan

http://dx.doi.org/10.5716/WP16182.PDF

254. Potensi dan Tantangan dalam Pengembangan Skema Ko-Investasi Jasa Lingkungan di Kabupaten Buol, Indonesia. http://dx.doi.org/10.5716/WP17008.PDF

255. Keragaman Jenis Pohon dan Pemanfaatannya oleh Masyarakat di Kabupaten Buol, Indonesia. http://dx.doi.org/10.5716/WP17009.PDF

256. Kerentanan dan preferensi sistem pertanian petani di Kabupaten Buol, Indonesia http://dx.doi.org/10.5716/WP17010.PDF

257. Dinamika Perubahan Penggunaan/Tutupan Lahan Serta Cadangan Karbon di Kabupaten Buol, Indonesia. http://dx.doi.org/10.5716/WP17011.PDF

258. The effectiveness of the volunteer farmer trainer approach vis-à-vis other information sources in dissemination of livestock feed technologies in Uganda.

http://dx.doi.org/10.5716/WP17104.PDF

259. Agroforestry and forestry in Sulawesi series: Impact of agricultural-extension booklets on community livelihoods in South and Southeast Sulawesi.

http://dx.doi.org/10.5716/WP17125.PDF

260. Petani Menjadi Penyuluh, Mungkinkah? Sebuah Pendekatan Penyuluhan dari Petani ke Petani di Kabupaten Sumb Timur. http://dx.doi.org/10.5716/WP17145.PDF

261. Dampak Perubahan Tutupan Lahan terhadap Kondisi Hidrologi di Das Buol, Kabupaten Buol, Sulawesi Tengah: Simulasi dengan Model Genriver http://dx.doi.org/10.5716/WP17146.PDF

262. Analisis Tapak Mata Air Umbulan, Pasuruan, Jawa Timur. Kajian elemen biofisik dan persepsi masyarakat. http://dx.doi.org/10.5716/WP17147.PDF

263. Planned comparisons demystified. http://dx.doi.org/10.5716/WP17354.PDF 264. Soil health decision support for NERC digital soil platforms: A survey report.

http://dx.doi.org/10.5716/WP17355.PDF

265. Seri Pembangunan Ekonomi Pedesaan Indonesia: Menanam di bukit gundul: Pengetahuan masyarakat lokal dalam upaya restorasi lahan di Sumba Timur. http://dx.doi.org/10.5716/WP17356.PDF 
266. Tree diversity and carbon stock in three districts of Kutai Timur, Pasir and Berau, East Kalimantan http://dx.doi.org/10.5716/WP17357.PDF

267. Tree Diversity and Carbon Stock in Various Land Use Systems of Banyuasin and Musi Banyuasin Districts, South Sumatera http://dx.doi.org/10.5716/WP17358.PDF

268. Tree diversity and carbon stock in various land cover systems of Jayapura, Jayawijaya and Merauke Districts, Papua Province http://dx.doi.org/10.5716/WP17359.PDF

269. Modelling tree production based on farmers' knowledge: case for kapok (Ceiba pentandra) and candlenut (Aleurites mollucana) under various agroforestry scenarios. http://dx.doi.org/10.5716/WP17361.PDF

270. The Impact of Land Cover and Climate Change on Present and Future Watershed Condition. Study case: Tugasan, Alanib and Kulasihan Sub-watershed of Manupali Watershed, Lantapan, Bukidnon, Philippines. http://dx.doi.org/10.5716/WP17362.PDF

271. Tree Diversity and Above-ground Carbon Stock estimation in Various Land use Systems in Banjarnegara, Banyumas and Purbalingga, Central Java.

http://dx.doi.org/10.5716/WP17363.PDF

272. Agroforestry and Forestry in Sulawesi series: Landscape Management Strategies in Sulawesi: Review of Intervention Options. http://dx.doi.org/10.5716/WP17364.PDF

273. Household Food-Security and Nutritional Status of Women and Children in Buol Regency, Central Sulawesi, Indonesia. http://dx.doi.org/10.5716/WP17365.PDF

274. Palm oil expansion in tropical forest margins or sustainability of production? Focal issues of regulations and private standards. http://dx.doi.org/10.5716/WP17366.PDF

\section{8}

275. Decision analysis methods guide: Agricultural policy for nutrition. http://dx.doi.org/10.5716/WP18001.PDF

276. Supporting human nutrition in Africa through the integration of new and orphan crops into food systems: Placing the work of the African Orphan Crops Consortium in context. http://dx.doi.org/10.5716/WP18003.PDF

277. Seri Pembangunan Ekonomi Pedesaan Indonesia. Pilihan Manajemen Budidaya Kacang Tanah sebagai Upaya untuk Memperbaiki Penghidupan Masyarakat Haharu. http://dx.doi.org/10.5716/WP18004.PDF

278. Estudio de línea de base CCAFS a nivel de hogar en Nicaragua y Costa Rica Fase de diagnóstico del estudio: "Contribución de la diversidad arbórea a los medios de vida para la adaptación y la mitigación al cambio climático http://dx.doi.org/10.5716/WP18005.PDF 
279. Understanding tree cover transition, drivers and stakeholder perspectives for effective landscape governance. A case study in Na Nhan commune, Dien Bien province, Vietnam. http://dx.doi.org/10.5716/WP18006.PDF

280. El Sistema “Quesungual”: Agroforestería y manejo de suelos para la producción de maíz y frijol en laderas. http://dx.doi.org/10.5716/WP18007.PDF

281: Probabilistic Decision Modelling to Determine Impacts on Natural Resource Management and Livelihood Resilience in Marsabit County, Kenya. http://dx.doi.org/10.5716/WP18008.PDF

282. Shifting discourse, shifting power: how is climate change mitigation and justice negotiated in Indonesia? http://dx.doi.org/10.5716/WP18009.PDF

283. Result of Land Use Planning and Land Administration (LULA) Implementation in South Sumatra, East Kalimantan, Central Java and Papua http://dx.doi.org/10.5716/WP18010.PDF

284. Farmers' preferences for training topics and dissemination of agroforestry information in Indonesia. http://dx.doi.org/10.5716/WP18015.PDF

285. CSA-Diagnostic (CSA-Dx): A primer for investigating the 'climate-smartness' of ag technologies http://dx.doi.org/10.5716/WP18020.PDF

286. An analysis of the vulnerability of poor communities in Yunnan Province, China http://dx.doi.org/10.5716/WP18021.PDF

287. Gendered space and quality of life: gender study of out-migration and smallholding agroforestry communities in West Java Province, Indonesia.

http://dx.doi.org/10.5716/WP18024.PDF

288: Evaluation of UTZ certification coffee businesses in Guatemala, Honduras and Nicaragua. http://dx.doi.org/10.5716/WP18028.PDF

289. Agroforestry species of Peru: annotated list and contribution to prioritization for genetic conservation. http://dx.doi.org/10.5716/WP18029.PDF

290. Indonesia Rural Economic Development Series.Growing plants on a barren hill: local knowledge as part of land restoration in Sumba Timur, Indonesia.

http://dx.doi.org/10.5716/WP18030.PDF

291. Assessing the Downstream Socioeconomic Impacts of Agroforestry in Kenya http://dx.doi.org/10.5716/WP18033.PDF

\section{9}

292: Los árboles fuera del bosque en la NAMA forestal de Colombia. Elementos conceptuales para su contabilización. http://dx.doi.org/10.5716/WP19002.PDF 
293: Gender and Adaptation: An Analysis of Poverty and Vulnerability in Yunnan, China. http://dx.doi.org/10.5716/WP19004.PDF

294: Tree Cover on Agricultural Land in the Asia Pacific Region. http://dx.doi.org/10.5716/WP19005.PDF

295: What do we really know about the impacts of improved grain legumes and dryland cereals? A critical review of 18 impact studies.vhttp://dx.doi.org/10.5716/WP19006.PDF

296: Breeders' views on the production of new and orphan crops in Africa: a survey of constraints and opportunities. http://dx.doi.org/10.5716/WP19007.PDF

297: Biomass Resources in Rhino Camp and Imvepi Refugee Settlements and the Buffer Zone around these Settlements in West Nile, Uganda. http://dx.doi.org/10.5716/WP19031.PDF

298: Option for restocking woody biomass in refugee-hosting areas: Perspectives from communities in Rhino Camp and Imvepi Settlements, Uganda.

http://dx.doi.org/10.5716/WP19032.PDF

299: Restoring ecosystems in refugee settlements using tree-based systems: The case of Rhino Camp and Imvepi Settlements in Uganda.

http://dx.doi.org/10.5716/WP19033.PDF

300: A theory-based evaluation of the Agroforestry Food Security Programme, Phase II in Malawi (AFSPII): Lessons for Scaling Up Complex Agronomic and Natural Resource Management Practices Developed and Tested in Research Settings. http://dx.doi.org/10.5716/WP19036.PDF

301: Fuentes semilleras y especies agroforestales de los bosques secos tropicales del norte del Perú: estado actual y prioridades futuras. (Spanish)

http://dx.doi.org/10.5716/WP19057.PDF

302: Seed sources and agroforestry species of tropical dry forests of northern Peru: current status and future priorities. (English)

http://dx.doi.org/10.5716/WP19058.PDF

303: Turmeric Production under Shade Management and Fertilization in Degraded Landscapes of Sumba Timur.

http://dx.doi.org/10.5716/WP19066.PDF

2020

304: From Tree Planting to Tree Growing: Rethinking Ecosystem Restoration Through Trees. http://dx.doi.org/10.5716/WP20001.PDF

305: Agroforestry species of Peru: Reference list and contribution to prioritization for the conservation of agroforestry genetic resources.

http://dx.doi.org/10.5716/WP20013.PDF 
306: An exploratory analysis of cost-benefit analysis of landscape restoration.

http://dx.doi.org/10.5716/WP20014.PDF

307: Wood fuel value chains in Kenya: a 20-year synthesis.

http://dx.doi.org/10.5716/WP20026.PDF

308: Especies agroforestales del Perú: Lista referencial y contribución a la priorización para la conservación de recursos genéticos agroforestales. Documento de Trabajo número 308.

Centro Internacional de Investigación Agroforestal

http://dx.doi.org/10.5716/WP20041.PDF

309: Simulasi Dampak Perubahan Tutupan Lahan dan Curah Hujan di DAS Citarum Hulu dengan Model GenRiver: Kalibrasi model dan analisa sensitivitas.

http://dx.doi.org/10.5716/WP20048.PDF

310: Simulating the effect of change in land cover and rainfall in Upper Citarum Watershed: calibration and sensitivity analysis of Genriver model

http://dx.doi.org/10.5716/WP20049.PDF

311: Status of Perennial Tree Germplasm Resources in India and their Utilization in the Context of Global Genome Sequencing Efforts. http://dx.doi.org/10.5716/WP2020050.PDF

312: The one hundred tree species prioritized for planting in the tropics and subtropics as indicated by database mining. World Agroforestry, Nairobi, Kenya.

http://dx.doi.org/10.5716/WP21001.PDF

313: Amaruzaman S, Isnurdiansyah B L. 2021. Land-use Land-cover Change and Farming systems in the upland of Pagar Alam City, Indonesia. http://dx.doi.org/10.5716/WP21007.PDF

314: Effect of COVID-19 on rural community enterprises: the case of community forest enterprises in Cameroon.

http://dx.doi.org/10.5716/WP21007.PDF

315: Assessment of women's benefits and constraints in participating in agroforestry exemplar landscapes. https://dx.doi.org/10.5716/WP21021.PDF 
World Agroforestry (ICRAF) is a centre of scientific and development excellence that harnesses the benefits of trees for people and the environment. Leveraging the world's largest repository of agroforestry science and information, we develop knowledge practices, from farmers' fields to the global sphere, to ensure food security and environmental sustainability.

ICRAF is the only institution that does globally significant agroforestry research in and for all of the developing tropics. Knowledge produced by ICRAF enables governments, development agencies and farmers to utilize the power of trees to make farming and livelihoods more environmentally, socially and economically sustainable at multiple scales.

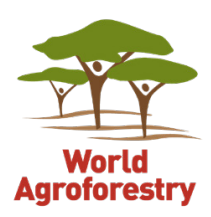

United Nations Avenue, Gigiri • PO Box 30677 • Nairobi, $00100 \cdot$ Kenya Telephone: +254207224000 or via USA +1 6508336645 Fax: +254207224001 or via USA +1 6508336646 Email: worldagroforestry@cgiar.org•www.worldagroforestry.org 